\title{
DEMOCRACIA, PLURALIZAÇÃO DA REPRESENTAÇÃO E SOCIEDADE CIVIL
}

\author{
Adrián Gurza Lavalle \\ Peter P. Houtzager \\ Graziela Castello
}

A representação política nas democracias contemporâneas sofreu transformações profundas no último quartel do século XX: partidos políticos de massas perderam sua centralidade como ordenadores estáveis das identidades e preferências do eleitorado; a personalização midiática da política sob a figura de lideranças plebiscitárias tornou-se um fenômeno comum; mudanças no mercado de trabalho tornaram instáveis e fluidas as grandes categorias populacionais outrora passíveis de representação por sua posição na estrutura ocupacional; e, se isso não bastasse, uma vaga de inovações institucionais tem levado a representação política, no Brasil e pelo mundo afora, a transbordar as eleições e o legislativo como lócus da representação, enveredando para o controle social e para a representação grupal nas funções executivas do governo. $\mathrm{O}$ nosso conhecimento sobre a relação entre a reforma da democracia - no sentido do seu aprofundamento - e os processos de pluralização dos atores da representação, e de diversificação do lócus onde ela é exercida, encontra-se em uma posição curiosa, por assim dizer. Os autores que têm se dedicado mais criteriosa e rigorosamente à análise do funcionamento da repre- 
sentação política, e dos processos de sua transformação, pouco têm-se preocupado com a qualidade e reforma da democracia ou, no melhor dos casos, têm-no feito de modo muito restritivo. De outro lado, autores debruçados sobre o aprimoramento da qualidade da democracia e, nesse sentido, orientados para a definição de uma agenda de reforma, pouca atenção têm prestado à questão da representação, a não ser para denunciar suas mazelas ou limitações e valorizar a democracia participativa. Em palavras mais sintéticas, embora de modo brutalmente esquemático, quem pensa a representação política tem atentado pouco para a reforma da democracia e vice-versa.

Essas literaturas parecem manifestar reações diferentes diante de um dilema crucial: a despeito das mudanças generalizadas nas relações entre partidos, candidatos e eleitores, e malgrado o fato de novas instâncias de intermediação - como a mídia e miríades de atores societá50 rios - estarem a desempenhar aqui e alhures funções que acusam alterações de envergadura no governo representativo, inexistem modelos consagrados histórica ou analiticamente para problematizar tais funções em termos de representação propriamente política ou para se pensar em novas modalidades democráticas de conexão entre representantes e representados. Assim, os estudiosos dedicados a esquadrinhar as transformações da representação oferecem interpretações de uma reconfiguração em curso ao nível do sistema partidário, no qual estaria se redefinido a relação entre representantes eleitos e cidadãos representados ${ }^{1}$.

1. A relação entre representantes e representados tem sido intensamente estudada nos Estados Unidos, focando a atenção nas eventuais conexões entre as tomadas de decisões - no legislativo - dos políticos eleitos e os interesses ou preferências dos eleitores. Aqui foi abarcado um conjunto de trabalhos muito menor e mais recente, suscitado a partir dos debates sobre a reconfiguração da representação política: Manin (1997); Przeworski, Stokes e Manin (1999); Novaro (2000); Miguel (2003a; 2003b), entre outros. 
Dessa perspectiva, a representação está integralmente condensada nos processos eleitorais e, no limite, pode ser favorecida pela divisão do poder dentro do Estado e do aparato burocrático; por este motivo, nem sequer cabe cogitar eventuais funções de representação política fora dos circuitos tradicionais da política. Já os estudiosos do aprofundamento da democracia têm enfocado inovações institucionais que visam a acolher diversas formas de participação no desenho e implementação de políticas públicas, mas sem prestar atenção à problemática da representação. Isto, apesar de a compreensão das dinâmicas de representação política presentes no interior da sociedade civil constituir fronteira crítica para o debate contemporâneo sobre o aprofundamento da democracia.

Porém, as disputas teóricas e práticas pela reforma da democracia parecem estar se deslocando gradativamente para a questão da representação, e as análises sobre a representação, por sua vez, vêm atentando para a questão da representatividade da democracia. Com efeito, nas abordagens institucionais da ciência política e entre defensores exímios de compreensões minimalistas da democracia é possível apreciar tanto o reconhecimento dos déficits de representatividade das instituições democráticas quanto tentativas de explorar possibilidades de reforma da democracia para construir maior capacidade de controle social sobre as decisões políticas e a sua implementação. Por outro lado e embora vagarosamente, as tentativas de alargar e redefinir a representação vêm crescendo com feições mais ousadas fora dessas abordagens, nas literaturas voltadas para o aprofundamento da democracia. Entrementes, o registro distintivo dos diversos debates travados por essas literaturas ainda encontra-se cifrado em termos que negligenciam a questão da representação, fundamentalmente como conseqüência da centralidade neles conferida à idéia de "participação" e a uma compreensão da "sociedade civil" altamente estilizada 
e capaz de unificar uma miríade de atores societários diversos dentro de uma lógica comum.

Independentemente de os efeitos eventualmente positivos ou negativos das transformações da representação para a reforma da democracia aguardarem ainda diagnósticos cabais, parece difícil negligenciar o fato de semelhantes diagnósticos requererem, antes, uma revisão crítica dos pressupostos que alicerçam a nossa compreensão da representação política. Situado em espaço intermediário entre as abordagens mais tradicionais da ciência política e as literaturas sobre aprofundamento da democracia, e mediante balanço do estado atual do debate, este artigo visa a iluminar a conexão entre a reforma da democracia e as transformações em curso na representação política; transformações no sentido da pluralização dos atores com investidura para realizá-la e da diversificação dos lugares em que é exercida.

52 Argumenta-se aqui, primeiro, que os dilemas da representatividade são inerentes à representação política moderna, cujas potencialidades máximas aparecem particularmente cristalizadas nos limites estruturais do mecanismo eleitoral para garantir a representatividade das instituições da democracia. Segundo, mostra-se que tais limites interpelam à teoria democrática, inclusive às suas vertentes minimalistas e procedimentais, não apenas evidenciando insuficiências críticas no coração dos arcabouços institucionais da representação política, mas mostrando a pertinência das preocupações em reformar a democracia de modo que ela se torne mais responsiva. Terceiro, defende-se que os deslocamentos operados nas abordagens procedimentais da ciência política, bem como nas literaturas empenhadas no aprofundamento da democracia, são ainda insuficientes para ancorar esforços de reconceitualização da representação política à altura do desafio da reforma da democracia e dos processos reais de inovação institucional democráti- 
ca ocorridos nas últimas décadas. Por fim, aponta-se para uma agenda de reflexão. Com maior precisão, sustenta-se que o fenômeno do alargamento da representação política, em andamento aqui e alhures, guarda semelhanças relevantes com a idéia de "representação virtual", cunhada por Edmund Burke. Procuramos mostrar, na última parte do artigo, que o resgate crítico dessa categoria insinua um horizonte analítico sugestivo para reelaborar a relação entre ampliação da democracia e representação política.

\section{Estatuto dual da representação e limites das eleições}

A representação foi originariamente figura do direito privado e nesse âmbito se manteve, inclusive como expediente de representação política, durante o medievo: os representantes junto ao poder régio eram mandatários, embaixadores ou agentes autorizados de interesses privados, agindo em nome dos seus contratantes para interceder com instruções específicas perante o Rei (Galvão, 1971; Pitkin neste volume [1989]: 15-47)². Guardadas todas as ressalvas devidas, lógica semelhante foi preservada nas diversas figuras da representação no direito civil moderno: nas procurações como instrumento de cessão de poderes com mandato claramente delimitado; no direito de representação em matéria de sucessões, particularmente quando os herdeiros não são juridicamente qualificados para agir sem intermediários; ou nas diferentes representações ex oficium estabelecidas por lei, como, por exemplo, em caso de incapacidade (Galvão, 1971: 3-11; 45-47). Do ponto de vista do direito, a representação privada ou civil é autêntica, isto é, propriamente representação, pela con-

2. O uso dominante da idéia de representação na Idade Média foi eminentemente simbólico em sentido místico: a personificação de Cristo, dos apóstolos e da comunidade cristã no Papa ou de uma comunidade territorial unificada no corpo místico do Rei (Pitkin neste volume. ([1989]: 15-47) 
fluência de um mandato imperativo - instruções quanto à matéria da representação - com a responsabilização plena do representante que pode ser acionado juridicamente pelo representado em caso de quebra do mandato. Assim, os dilemas da representatividade não afetam a representação no mundo privado. Nele a representação se esgota na norma e no contrato que autorizam a procuração de interesses em assuntos nitidamente delimitados; o representante é mandatário sem autonomia decisória, possui um mandato imperativo. Por outras palavras, a coincidência entre a vontade do representado e as decisões do representante, graças ao mandato imperativo, cancela ou torna carente de sentido a questão da representatividade.

O contraste com a representação política própria do governo representativo não poderia ser maior. Ela leva no seu cerne uma dualidade constitutiva graças à qual a mera existência da representação, mesmo que legalmente institu54 ída ou respaldada por mecanismo obrigatório de autorização, não garante a representatividade ou correspondência com a vontade ou interesse dos representados. A relação entre representante e representado assume o caráter de uma conexão/desconexão a determinar o quão representativos são as instituições e os agentes da representação política. De um lado, ao mandato imperativo da representação no direito privado corresponde um mandato delegativo ou representativo que garante a autonomia do representante para agir em função do seu juízo e raciocínio, priorizando o todo sobre as partes, ou o interesse da nação sobre o interesse particular dos eleitores - "uma nação com um interesse" conforme expresso por Edmund Burke no Discurso canônico aos eleitores de Bristol (1942: 312-313 [1774]; grifo no original). A esse respeito é peculiarmente elucidativa a confluência das tradições político-ideológicas anglo-saxônica e francesa. A invocação do "interesse da nação", alicerçado em uma compreensão pluralista de interesses entre 
partes - própria da tradição anglo-saxônica -, coincide no plano da representação com o papel do "bem da nação" ou "vontade geral" característicos do racionalismo francês (Rosanvallon, 1992: 137-167). Dois anos após a revolução francesa, a Constituição de 1791 especificou, para erradicar quaisquer mal-entendidos, que "os representantes nomeados nos departamentos não serão representantes de um determinado departamento, mas da nação inteira" (citado por Sartori, 1962: 19) ${ }^{3}$. Sabe-se que disposições políticas semelhantes tornaram-se comuns às Constituições modernas (Manin, 1995).

Do outro lado, é consensual que responsabilização do representante no direito civil - sua imputabilidade - apenas encontra na representação política correspondência laxa centrada na responsividade e prestação de contas entre o representante eleito e o representado ${ }^{4}$. Com maior precisão, as eleições constituem um mecanismo de sanção sobre os representantes (accountability) e tendem a estimular a sensibilidade destes perante as demandas e necessidades dos representados (responsiveness). Nas palavras de Hanna Pitkin (1967: 213), “[...] o representante deve visar ao interesse dos representados de maneira pelo menos potencialmente responsiva aos seus anseios, e [...] o conflito entre eles deve ser justificável em termos desse interesse" ${ }^{5}$.

3. Sartori (1962: 19-29) argumenta que a representação política abandona sua matriz privatística aproximadamente um século antes da revolução francesa. A disposição da Constituição Francesa e inclusive a famosa fórmula de Burke expressariam, assim, uma concepção e uma prática amplamente difundidas e consolidadas.

4. Para diversas expressões desse consenso, ver, por exemplo, os trabalhos de Manin, Przeworski e Stokes (1999a); Przeworski (2002); Arato (2002); Sartori (1962: 47-57). Para uma exposição introdutória do papel da responsividade na representação política, ver o trabalho de Campilongo (1988).

5. Tradução nossa. Também as demais passagens vertidas para o português no artigo. 
Destarte, a representação política supõe uma dualidade constitutiva entre representação e representatividade, entre representante e representado. Diversos desdobramentos desta dualidade têm dominado a história política e intelectual da representação política no mundo moderno: a autonomia do representante versus o mandato dos representados; o componente institucional legal ou formal da representação versus o seu componente substantivo ou de formação de vontade; o peso da delegação ou elemento fiduciário versus o peso da autorização ou elemento do consentimento; a soberania nacional ou primazia simbólica e política do todo versus a soberania popular ou primazia dos reclamos e exigências dos eleitores; as posturas majoritárias quanto à composição do parlamento versus as posturas proporcionais; sem esquecer, é claro, a oposição mais geral entre legalidade ou facticidade e legitimidade ou validade. Embora a compreensão da natureza desses binômios admi56 ta certa controvérsia ${ }^{6}$, trata-se de uma dualidade constituti-

6. Pitkin (1967) analisa essa série de binômios como uma tensão entre os propósitos originais da representação política e a sua institucionalização. Para a autora, abraçar de modo unilateral apenas um dos pólos da tensão gera noções parciais de representação; curiosamente, alguns anos depois (Pitkin neste volume [1989]:15-47), parece ter optado por um desses pólos, ou melhor, pela democracia direta porque capaz de manter o valor intrínseco da política e de evitar que ela se torne privilégio de alguns poucos. Sartori (1962) concebe a relação entre os elementos dessas dualidades em termos de uma tensão constitutiva da representação política no mundo moderno, derivada do fato de ela ter se cristalizado com caráter duplo: como representação no poder (função governo) e como representação perante o poder (função legitimidade). Por sua vez, para Manin (1995), a conexão entre representante e representado encontra-se plenamente instituída dentro dos princípios do governo representativo, quer mediante a autorização eleitoral, quer mediante o papel da opinião pública; contudo, não parece descabido afirmar que, para o autor, seria um despropósito se pensar nos componentes dessas dualidades como antinomias ou tensões, visto que na sua gênese o governo representativo não teria sido projetado por seus fundadores como uma democracia; antes, teria sido construído para preservar a distância entre representantes e representados. Embora historicamente correta, a postura de Manin parece não outorgar suficiente importância ao fato de as eleições não serem apenas um componente institucional estável do governo representativo, mas também consagrarem um princípio normativo: os representantes devem atuar em benefício dos representados e, por isso, devem ser submetidos regularmente a eleições. 
va na medida em que a construção político-institucional e a conceituação teórica ou prática da representação política passam, ora por assumir uma tensão indissolúvel entre ambos os pólos, ora por conferir prevalência a um deles, sem, no entanto, cindi-los por completo. Preservar analiticamente apenas os diversos desdobramentos de um ou outro pólo dessa tensão, conforme mostrado com parcimônia por Sartori (1962) e Pitkin (1967), é o caminho mais curto para esvaziar a representação política: se privilegiado o pólo formal-institucional do representante perde-se o conteúdo substantivo da representação como atuação para o interesse ou benefício do representado; se privilegiado o pólo substantivo de formação de vontade do representado, perde-se o conteúdo político da representação enquanto cristalização institucional arquitetada para organizar o governo da e sobre a sociedade. Assim, se a autonomia política do representante não pode ser perseguida a ponto de esgarçar definitivamente sua relação com o eleitorado, o fortalecimento da representatividade tampouco pode ser buscado às custas de anular tal autonomia.

Se a representação política é constituída por uma dualidade que coloca no centro a problemática da representatividade, quer dizer, da maior ou menor legitimidade da representação efetivamente exercida pelo representante, torna-se crucial averiguar quão efetivas são as instituições e os processos da representação política para evitar a total desconexão entre eleitos e eleitores - ou, se se quer, para promover modalidades de conexão. O modelo dominante de representação política que organiza as democracias contemporâneas, cristalizado nos séculos XVIII, XIX e XX, entrelaçou legislativo como lócus da representação, políticos eleitos, eleições e eleitores, e, mais tardiamente, partidos políticos de massas como instâncias de mediação e ordenação da relação entre representantes e representados. Essa configuração da representação política, consubstanciada 
na fórmula "governo representativo", estabelece definições claras quanto a quem representa (o político), mediante que mecanismos é autorizado a representar e a que tipo de sanção ou controles estará submetido (as eleições), quem é representado (o eleitor), e de alguma forma, ainda que muito vaga, qual o conteúdo ou mandato a ser representado (programa, promessas de campanha).

Sem dúvida, a montagem de um processo de representação política submetida a tais especificações define um sistema empírico de funcionamento e, a um só tempo, projeta um núcleo normativo mínimo, a saber, “[...] atuar em favor do interesse do representado” (Manin et al., 1999: 2) ${ }^{7}$. Esse núcleo normativo permite avaliar a representação política do ponto de vista da sua representatividade sem lançar mão de parâmetros externos - sempre definidos por um terceiro - , centrando a atenção apenas em determinados critérios de congruência do comportamento e decisões do repre58 sentante eleito em relação às necessidades, preferências e anseios do representado ${ }^{8}$.

Porém, e malgrado o grau de especificação dos componentes da representação política moderna, há sérias contro-

7. Pitkin (1967: 209) apenas acrescentaria um elemento pontual a esse núcleo mínimo: "atuar em favor do representado de modo responsivo".

8. O modelo de congruência constitui a abordagem mais influente nas análises empíricas sobre representação política realizadas na segunda metade do século XX - particularmente no campo da ciência política (Campilongo, 1988). Como indicado no próprio nome, o modelo postula que a avaliação da representação pode ser equacionada em termos de maior ou menor congruência - representatividade - entre o comportamento dos representantes eleitos e as preferências dos seus eleitores; em que o comportamento dos primeiros se torna aferível mediante a produção de políticas públicas legislativas, enquanto as preferências dos segundos aparecem condensadas nos resultados eleitorais ou em estudos de opinião. Malgrado as críticas dirigidas contra o modelo ao longo dos anos, o espírito da noção de congruência parece incontestável sem colocar em xeque os fundamentos da própria representação política; isto é, seu núcleo normativo mínimo. O modelo de congruência também tem sido utilizado para analisar a representatividade de governos em relação aos seus partidos. A esse respeito, ver o estudo comparativo de 10 países realizado por Klingemann et al. (1994). 
vérsias e ressalvas quanto à capacidade das eleições de tornar governos realmente representativos. Primeiro, embora o princípio da maioria equacione a definição daquilo que deva ser efetivamente representado - "interesse geral" ou "vontade da maioria" -, desde as reflexões do Marquês de Condorcet (1785), há sólido repertório de críticas técnicas ou de método quanto à impossibilidade de se produzir diagnósticos ou maximizações desse "interesse geral” a partir da agregação de votos (Arrow, 1951) ${ }^{9}$. Segundo, mesmo se admitindo que, na representação política, a responsividade substitui a responsabilidade - responsabilização do representante -, o voto estimula, mediante a prestação de contas, um controle extremamente laxo sobre as decisões dos políticos eleitos e francamente nulo sobre as burocracias encarregadas de implementá-las (Przeworski et al., 1999). Terceiro, no contexto midiático das democracias contemporâneas, os conteúdos genéricos do mandato representativo, conforme expressos nos programas e promessas de campanha, obedecem antes à lógica do cálculo estratégico conjuntural a respeito dos humores do eleitorado do que a compromissos substantivos com determinados cursos de ação política a serem efetivamente seguidos (Gingrass, 1998; Ferry et al., 1992) ${ }^{10}$. Em suma, definir em termos concretos quem ou o que deve

9. "Críticas técnicas" conforme a denominação utilizada por Dahl (1956: 38-44), embora pareça mais pertinente colocá-las no plano do método.

10. Há mais de meio século, ao inverter a direção do vetor "soberania popular => preferências de políticas => política”, Joseph A. Schumpeter (1980: 293-376 [1942]) identificou que os candidatos propunham políticas para se (re)eleger em vez de serem eleitos para realizar políticas definidas pela população; contudo, a mídia e os avanços dos estudos de opinião incorporados à comunicação política reduziram consideravelmente o componente de liderança e inovação associado à visão schumpeteriana de "propor políticas". Nos sistemas partidários fortemente competitivos, a estratégia discursiva de campanha encontra-se fortemente prefigurada pela composição de um campo estruturado em torno da polaridade situação/oposição (Figueiredo, 2000); por outro lado, o espaço para discursos centrados em clivagens ideológicas tem-se encolhido consideravelmente (Cervellini, 2000). 
ser efetivamente representado, ou se a representação política pode ser reputada como realmente representativa, é questão espinhosa mesmo no contexto das democracias e em se tratando de instituições plenamente cristalizadas, com tradição secular e sustentadas por amplo consenso social.

Eleições democráticas e representatividade distam de ser sinônimos não apenas devido a esses e outros fatores aventados na literatura, mas, sobretudo, pela existência de limites estruturais inerentes à própria configuração da representação política no governo representativo. A representação política moderna cumpre simultaneamente funções de legitimidade e funções de governo: de um lado, é representação perante o poder, quer dizer, defronte o Estado e o governo (poder executivo), e visa a fazer valer a voz e interesses do representado junto a e, se for preciso, contra essas instâncias ${ }^{11}$; do outro, trata-se de representação no poder, ou seja, é constituída como governo ou como 60 uma parte dele para mandar sobre a população, embora isso possa ser feito em nome do "governo do povo sobre o povo"12.Assim, mediante o voto são escolhidos representantes da população perante o poder, para controlá-lo, moderá-lo e orientá-lo nas decisões conforme as expectativas dos eleitores; entretanto, o voto também constitui os representantes como um poder sobre a população, munido com faculdades para tomar decisões vinculatórias e para obrigar a sua obediência. Giovanni Sartori (1962: 28) é enfático a esse respeito: a representação tem função

11. A representação perante o poder pode ser do legislativo perante o governo (executivo) ou perante o Estado, ou do próprio executivo perante o Estado; entretanto, normalmente remete à relação entre executivo e legislativo.

12. Uma feição distintiva da representação política moderna em face das modalidades de representação política praticadas no medievo reside, precisamente, na distância entre a representação pelo poder (encarnação), a representação junto ao poder (embaixador, deputado, enviado) e a representação no poder (Galvão, 1971: 17-56). A última figura é uma criatura do mundo moderno. 
dupla, "[...] não apenas a de tutelar os interesses dos mandantes, mas ao mesmo tempo a de governá-los [...] É esta a raiz de todos os problemas que agitam os sistemas parlamentares do nosso tempo" - é ela que subjaz às dualidades assinaladas $^{13}$.

$\mathrm{Na}$ linguagem da ciência política contemporânea, de matriz anglo-saxônica, diagnóstico idêntico sobre os limites estruturais da representação é passível de expressão na seguinte fórmula: como cidadão constituo um agente que, ao mesmo tempo, é meu principal ${ }^{14}$. Há, todavia, outra limitação, cuja pertinência depende de se assumir uma compreensão da representação própria do modelo do agente e do principal, no qual a relação entre representante e representado é analisada como uma relação entre dois indivíduos: um mandante e um mandatário, o eleitor e "seu" eleito $^{15}$. Dessa perspectiva, o voto também é um mecanismo utilizado com função dupla, o que impede a formulação de um mandato unívoco ou a expressão de alguma vontade clara a ser representada. De um lado, o eleitor emprega o voto como um mecanismo de sanção (accountability) sobre

13. Sartori continua (1962: 28): "Isto porque os parlamentos operam em condições de equilíbrio delicadíssimo. Assumem-se em demasia o ponto de vista dos governados, correm o risco de atrofiar e paralisar o governo. E se, pelo contrário, procuram absorvê-los demais no Estado [...] neste caso corre (sic) o risco de não preencher mais a sua função representativa".

14. Na verdade, tal formulação pode ser bem mais crua: "A peculiaridade da relação entre agente e principal na relação de representação política é que os nossos agentes são os nossos governantes: indicamo-los como agentes para que nos digam o que fazer e ainda damos-lhes autoridade para nos forçar a fazê-lo". (Manin et al, 1999a: 23-24)

15. "Representante" e "representado" são duas categorias que não necessariamente coincidem com os termos "eleitor" e "eleito"; basta trazer à memória a dualidade entre soberania nacional e soberania popular. Pitkin (1967: 221) atenta claramente para a conveniência de se abandonar a metáfora da relação de correspondência um a um - própria do modelo do agente e do principal - para entender a lógica da representação política. Para uma crítica do modelo de congruência, precisamente por pressupor essa correspondência, ver Campilongo (1988). 
a administração em gestão, avaliando retroativamente o desempenho; do outro, o voto sinaliza preferências (mandato) sobre políticas e opta entre as propostas de implementação futura apresentadas pela situação e pela oposição (Manin et al., 1999). Assim, embora as eleições tendam a induzir comportamentos responsivos dos representantes, pelo menos em algum grau, e institucionalizem prestações de contas periódicas, a ambigüidade inerente ao voto acusa seus limites intransponíveis como mecanismo de expressão de preferências.

\section{Representatividade: falso problema ou incontornável?}

Os limites estruturais do mecanismo eleitoral para promover o núcleo normativo mínimo da representação política, bem como as tensões inerentes ao conjunto de dualidades arroladas nos parágrafos anteriores, apenas questionam aqueles que assumem o caráter constitutivo desse núcleo

62 normativo ou aqueles que acreditam na viabilidade de algo semelhante à representatividade das instituições democráticas. Embora tal afirmação pareça um truísmo, na verdade há compreensões da representação à esquerda e à direita do espectro político para as quais a questão da representatividade constitui um falso problema. Grosso modo, é possível identificar dentro dessa postura perspectivas como o positivismo jurídico e abordagens centradas no direto civil, certo minimalismo extremo, e interpretações pós-modernas e democrata-radicais da representação política.

A questão da representatividade é um falso problema para as abordagens jurídicas do direito positivo na medida em que a representação política é resolvida como fato posto pela norma ou por uma forma institucional sancionada juridicamente. $O$ representante representa pelo simples fato de seu status de representante decorrer de modo pleno e suficiente das especificações procedimentais e funcionais consagradas na lei e de processos institu- 
cionais de autorização devidamente sancionados ${ }^{16}$. Nesse sentido, quaisquer indagações a respeito da congruência das decisões do representante em relação aos interesses do representado são expulsas do terreno legal e institucional da representação em si, e remetidas ao plano dos motivos subjetivos pelos quais cada indivíduo se sente representado, deslocando a problemática da representatividade para o terreno da psicologia ${ }^{17}$. A representação existe porque seu fulcro é uma norma positiva, mas o fato de ela ser em maior ou menor medida representativa é um juízo subjetivo e moral alheio à própria norma. Também no terreno do direito foi comum recusar a representação política como mera ficção que tomava emprestado o nome e o sentido da representação próprios do direito civil, sem contar, todavia, com alicerces jurídicos equivalentes: responsabilização ou imputabilidade do representante e mandato imperativo ou instruções quanto à matéria da representação (Sartori, 1962: 9-86). Nesses termos, a representação política seria uma ficção ideológica sem quaisquer fundamentos jurídicos.

Concepções minimalistas extremas também reduzem a representação política apenas aos seus componentes institucionais, mas fazem-no por motivos diferentes. Trata-se de "salvar" a representação depurando-a dos seus componentes normativos, mesmo se concebidos como núcleo normativo mínimo. Tal operação obedece ao intuito de

\footnotetext{
16. Para análises críticas do positivismo jurídico, ver os trabalhos de Sartori (1962: 12-19, 57-64), Campilongo (1988: 7-12, 45-57) e Galvão (1971: 3-56 ). Uma crítica do formalismo institucional pode ser consultada em Pitkin (1967: 38-58).

17. Crítica semelhante foi desenvolvida por Habermas (1980: 121-179) acerca do conceito de legitimidade em Weber, que, restrito às convenções sociais para se acreditar na legitimidade do poder (carisma, tradição, legalidade), esvazia o fundo normativo e de verdade da problemática da legitimidade. Neste caso, a representação simplesmente existe; o quão "verdadeira" é (legitimidade) constitui uma questão carente de sentido.
} 
separar a questão da legitimidade da questão da definição e existência de representação política em si; quer dizer, desvencilhada a representação política do seu núcleo normativo mínimo, sua definição “...de fato não implica atuar para favorecer os interesses de alguém e sequer a existência de qualquer mecanismo 'apropriado' de autorização e prestação de contas” (Rehfeld 2000: 2). Dessa perspectiva, a relação entre representante e representado existe de fato, independentemente de ela ser ou não representativa, pelo que a questão da representatividade deve ser expulsa do plano analítico da representação em si e ser reintroduzida apenas em uma teoria da legitimidade, opção que reputamos incorreta por esvaziar a dualidade constitutiva da representação política moderna, condensada no seu núcleo normativo mínimo.

Da perspectiva pós-moderna, a representação é interpretada como uma ficção em crise devido a causas acolhi64 das de modo entusiasta. Para dizê-lo com a semântica dessa literatura, a relação entre representante e representado foi sempre uma metáfora, uma metanarração verossimilhante de notável eficiência na geração de legitimidade política (Abal, 1996). A metáfora teria hoje perdido qualquer eficácia como dispositivo legitimador - daí a crise -, pois a homologia entre as instituições políticas e os grandes grupos de interesses próprios das sociedades fordistas fora irreversivelmente fraturada pela pluralização e diferenciação infrene do mundo social; diferenciação produtora de indivíduos escorregadios, inclassificáveis e dificilmente administráveis pelas velhas estruturas do monopólio da política (Lipovetski, 1986). Assim, a sociedade teria acabado por se tornar irrepresentável, inaugurando a era da política e da democracia pós-representativa. Se a perda de verossimilhança na relação entre representante e representado erodiu os pressupostos da democracia representativa, o pluralismo e a crescente proliferação de sentidos multívocos no mundo 
social apontariam como única alternativa para a representação da diferença, ou, melhor, da diferenciação como processo em que apenas se torna possível rastrear os vestígios de uma unidade do representável (Derrida, 1982).

A conhecida crítica de Rousseau (1982 [1762]: 14-30) à representação política como uma delegação da vontade geral, por princípio inalienável, é amostra emblemática do quão irreconciliável é a representação com concepções radicais da democracia, sejam elas republicanas, comunitárias, socialistas, libertárias ou versões enfáticas de democracia participativa ${ }^{18}$. Dessa perspectiva, a representação está sempre muito aquém de satisfazer exigências de representatividade, pois inevitavelmente produz uma deturpação da vontade política a ser representada devido à cisão entre representante e representado (Tenzer, 1992; Keane, 1988). Por outras palavras, e de modo geral, invocando o argumento errado da escala numérica e geográfica das sociedades contemporâneas, a democracia indireta é reduzida a um simples sucedâneo defeituoso da verdadeira democracia, que é direta e consubstancia o ideal do autogoverno, ou, no pensamento republicano, a soberania do corpo político (Araujo, 23-24) ${ }^{19}$. Visto que representar supõe tornar presente alguém ou algo mediante

18. Como bem lembra Bobbio (2000 [1984]: 60-61), pertencem à tradição do pensamento socialista as críticas à proibição do mandato imperativo, à representação de interesses gerais em vez de representações funcionais ou orgânicas de interesses de determinadas categorias sociais, e à irrevogabilidade do mandato. Por outro lado, visto que o valor da participação é compatível com a democracia liberal e com a presença de partidos como principais atores do processo político (Macpherson, 1978: 113-138; Bobbio, 2000 [1984]; Santos e Avritzer, 2003), tornase prudente qualificar de enfáticas as compreensões da democracia participativa que conferem à representação o estatuto de um mal-necessário.

19. Para uma crítica histórica do uso idealizado das democracias diretas greco-latinas como parâmetro de avaliação da democracia moderna, assumindo se tratar de modelo disponível e exeqüível, ver o trabalho de Sartori (1994: 34-58). A esse respeito, Manin (1997: 42-93) desenvolve um exercício primoroso de distanciamento entre o republicanismo e a construção histórica do governo representativo. Para críticas recentes aos teóricos da democracia participativa por ignorarem a questão da representação, ver Urbinati (1999) e Warren (2005). 
a figura de algum intermediário, não existe algo semelhante a "auto-representação", que, na verdade, é apresentação ou presença-participação. O déficit de representatividade é resolvido, assim, cancelando a própria representação.

Para essas posturas, a questão da representatividade é um falso problema, ora porque a representação existe e se constitui de forma plena no plano meramente institucional, ora devido a seu caráter ficcional ou à impossibilidade de resolver essa questão enquanto for mantida a delegação que separa representante e representado. A rigor, também careceria de sentido pensar em uma suposta crise da representação nas democracias contemporâneas - a não ser no plano da percepção -, pois quaisquer mudanças eventualmente responsáveis por ela, apenas evidenciariam para segmentos amplos da população aquilo que já era conhecido no campo dos especialistas acadêmicos, a saber, a impossibilidade de assegurar ou estreitar o vínculo entre representante e 66 representado.

Porém, a operação analítica prudente para não suprimir as características tipicamente modernas da representação tem sido, pelo menos desde a formulação canônica de Burke (1942 [1774]), preservar o núcleo normativo mínimo da representação de modo que se garanta a independência do representante sem emancipá-lo completamente do controle do representado (Pitkin, 1967: 1-13, 209-240; Sartori, 1962: 19-29, 47-57; Bobbio, 2000 [1984]: 53-76; Przeworski et al., 1999: 2-3). Isto é, a representatividade das decisões políticas - ou, por outras palavras, se, em alguma medida, o representante age em benefício do representado -, continua a ser um problema incontornável da teoria democrática, inclusive para renomados defensores de compreensões minimalistas da própria democracia ${ }^{20}$.

20. Ver a análise da próxima seção. 


\section{Transformações da representação e a democracia}

A longo do último quartel do século XX tornou-se lugar comum a afirmação de que a vitalidade e qualidade da democracia acusavam os efeitos corrosivos e despolitizadores das transformações estruturais acontecidas no plano da economia e do Estado, comprometendo a capacidade de representação de interesses tal como fora cristalizada pela consolidação da democracia de partidos e do sindicalismo como expediente de representação funcional. Assim, às críticas contra-culturais dos anos 1960, e às tentativas analíticas coevas de alargar participativamente a democracia (Pateman, 1970) para além do seu figurino liberal, foi acrescido, nos seguintes decênios, um conjunto de transformações estruturais que o pensamento acadêmico e político significaram mediante a multiplicação do vocábulo "crise": dos partidos, da política, da democracia, da representação.

Entre os autores preocupados com as transformações ou eventual crise da representação política, quiçá o exemplo mais notável e analiticamente requintado na literatura seja o trabalho de Bernard Manin (1997). O autor sustenta a existência de semelhanças notáveis entre o momento atual e o momento da transição do modelo parlamentar liberal de representação para a democracia de partidos, em que esses institutos políticos emergiram como nova instância de intermediação entre o voto dos representados e os representantes. À época, tinha-se a sensação de uma crise geral da representação política, regada com interpretações alarmadas atentando para os efeitos fatalmente corrosivos das novas instâncias de mediação - os partidos de massas sobre o sistema liberal clássico parlamentar. O decorrer do tempo tornou claro que os partidos de massas não ruíram o governo representativo, antes, acabaram nele incorporados alicerçando sua permanência sob novas condições históricas. A semelhança apontada por Manin serve ao propósito de defender que as denuncias contemporâneas das "crises" 
da democracia, da política, e dos partidos constituem manifestações de um processo de reconfiguração da representação que, hoje como outrora, não apenas não compromete as instituições do governo representativo, mas as repõe permitindo sua continuidade plena.

A volatilidade do eleitorado, a queda nos patamares de comparecimento nas urnas, o descrédito generalizado das instituições políticas, bem como outras múltiplas expressões do definhamento dos partidos de massas ${ }^{21}$, recebem confirmação nessa leitura, porém, no quadro de um prognóstico controverso: a reconfiguração da representação em curso incorporaria feições muito próximas do modelo parlamentar liberal, respeitando integralmente todos os princípios e características institucionais básicas da representação política moderna. Isso porque a figura do candidato e seus vínculos reais ou simbólicos com os eleitores teriam recuperado a importância perdida pela emergência dos partidos de 68 massas e das grandes clivagens programáticas e ideológicas, sem colocar em xeque as próprias eleições, nem os direitos políticos básicos da cidadania e sequer o mandato representativo ou autonomia dos representantes perante os desejos dos representados. Em última análise, emerge a mídia como elemento preponderante na "emancipação" dos candidatos em relação às estruturas partidárias, graças a sua capacidade de ligá-los simbolicamente com os eleitores dispensando a manutenção das custosas estruturas de enraizamento e mobilização dos partidos de massas. Por isso, a representação política característica da democracia de partidos estaria a ceder

21. Para uma análise de diferentes indicadores da perda de centralidade dos partidos do ponto de vista da reconfiguração da representação, ver Miguel (2003a) e Roberts (2002), além do trabalho de Manin em questão (1995: 193-234). Há diferentes perspectivas que fornecem razões para essa perda de centralidade, focando alternativamente fatores socioestruturais, político-institucionais ou de desempenho econômico. Para um teste da capacidade explicativa dessas perspectivas ver o trabalho de Roberts (1999). 
passo a uma representação política própria da democracia de públicos (audience democracy) (Manin, 1997: 218-234).

Não se trata de diagnóstico único no que diz respeito à proposta de equacionar a suposta crise da representação em termos de uma reconfiguração histórica. Por exemplo, em termos sem dúvida mais polêmicos, Marcos Novaro (2000) confere ao retorno de lideranças carismáticas no executivo federal o estatuto de peça-chave da reconfiguração da representação. O crescente pluralismo social e a diversificação das categorias socioeconômicas teriam levantado enormes dificuldades para o processamento de decisões vinculantes e para a construção de percepções coletivamente compartilhadas acerca de prioridades políticas e dos meios adequados para atingi-las. Perante tais dificuldades, e explorando em registro positivo aquilo que Bourdieu (1987) chamara de "fetichismo político da representação"22, o autor defende que lideranças plebiscitárias desempenhariam, hoje, a função de personificar a unidade da vontade social; unidade por certo inatingível mediante as instituições corporativas e políticas que espelharam e contribuíram para cristalizar as grandes clivagens sociais baseadas no mundo do trabalho fordista. Partidos e sindicatos teriam perdido a capacidade de costurar identidades amplas e, no seu lugar, as lideranças tenderiam cada vez mais a expandir seu papel de autoridade para assumir funções de criação de identidades ${ }^{23}$. O papel das lideranças plebiscitárias na reconfiguração da representação teria adquirido particular destaque na conjuntura da implementação das reformas estruturais das últimas déca-

$\overline{22 . ~ N o ~ s e u ~ c o n h e c i d o ~ a r t i g o ~ s o b r e ~ o ~ f e t i c h i s m o ~ d a ~ r e p r e s e n t a c ̧ a ̃ o, ~ B o u r d i e u ~ a p o n-~}$ ta para uma espécie de paradoxo da delegação, segundo o qual coletivos amplos não preexistem à representação, antes, ao enfrentar a disjuntiva entre "calar ou serem falados por outrem", passam a se constituir apenas a partir do momento em que se dotam de representante (Bourdieu, 1987: 158-172).

23. Para uma discussão acerca da importância da identidade interpretada como componente normativo da representação, ver Mokre (2002). 
das; reformas precedidas pelo quesito da construção de consensos sociais amplos ${ }^{24}$. Visto que a personalização da política em escala massiva requer os suportes técnicos fornecidos pelos meios de comunicação, também neste caso a mídia, e, em particular, uma série de fenômenos estudados no campo da comunicação política, emergem como alicerces do processo de reconfiguração da representação política.

Assim, nos seus diagnósticos acerca das transformações da representação, Manin, Novaro e outros autores (Miguel, 2003a; 2003b; Thompson, 2002) confluem ao apontar o papel preponderante da mídia como fator subjacente à reconfiguração por eles analisadas. Nesse sentido, incorporam à reflexão acerca da representação - temática quase exclusiva da ciência e filosofias políticas - um repertório de argumentos e conhecimentos avançados no campo da comunicação política, em que se tem atentado de modo insistente para a relevância de um espaço público midiático 70 capaz de elaborar a difícil auto-representação simbólica da sociedade e a relação desta com o mundo das instituições políticas (Ferry, 1992; Touraine, 1992; Wolton, 1992 e 1998; Thompson, 1998; Miége, 1998). A representação política (reconfigurada) seria ainda possível na medida que a construção de percepções comuns acerca de prioridades sociais e a conexão simbólica entre sociedade e governo, entre políticos e cidadãos, contam com a mídia como nova instância de mediação a desempenhar parcialmente um papel outrora reservado apenas aos partidos e a outras instâncias de unificação coorporativa como os sindicatos. Assim, contra leituras "apocalípticas" dos efeitos da mídia na política (v. gr. Debbor, 1998; Sartori, 1997), autores engajados nesse

24. Nesse perfil encaixariam claramente presidentes latino-americanos como Alberto Fujimori ou Carlos Menem, mas o "retorno do líder" (Zermeño, 1990) é fenômeno mais difundido e contemplaria figuras como Cuauhtémoc Cárdenas no México, ou os presidentes Fernando Collor no Brasil e Hugo Chávez na Venezuela. 
debate, e com eles Manin e Novaro, optam por equacionar os meios de comunicação não como substituição da política, mas como uma das suas condições de possibilidade no mundo contemporâneo ${ }^{25}$.

Porém, permanece em pé uma questão central. Embora seja um avanço notável mostrar que as chamadas "crises" da democracia, da política e dos partidos constituem, na verdade, interpretações imprecisas de transformações em curso - graças às quais a representação política estaria a se reconfigurar, permitindo o funcionamento das instituições do governo representativo e da democracia sob novas condições históricas -, cabe indagar os efeitos dessas transformações para a democracia. Quais, afinal, as conseqüências dessas transformações para a qualidade da democracia, que erodem a centralidade dos partidos políticos como ordenadores da relação entre representantes e representados, introduzindo a mídia e seus vínculos "intimistas" como novas instâncias de mediação? Por outras palavras, é relevante responder se as instituições da democracia serão mais ou menos representativas em decorrência da reconfiguração da representação.

Em Manin (1997), as instituições da democracia representativa sobrevivem vigorosas, mas disso não deriva nenhuma notícia positiva acerca de eventuais avanços, mesmo que mínimos, na representatividade da própria democracia. Quiçá a compreensão do autor quanto ao governo representativo como um modo de governo aristocrático contribua a explicar a desproporção entre sua eloqüência no diagnóstico da reconfiguração da representação política e o silêncio quanto às suas conseqüências para a democracia. Em Novaro (2000: 265-275), embora a personalização da política na figura da liderança plebiscitária permita processar decisões

25. Para balanços sobre o campo de estudos da comunicação política ver os trabalhos de Gosselin e Wolton na coletânea organizada por Gauthier et al. (1998). 
que aglutinam uma vontade política sobre o mundo, tampouco há quaisquer motivos para esperar que o decisionismo torne a democracia mais representativa. Ainda assim, para posturas outras que não aquelas que reputam a questão da representatividade um falso problema, a rarefação dos já tênues vínculos de comunicação e controle entre representantes e representados constitui um desafio para a própria democracia. O próprio pensamento de Manin (1999; e neste volume: 105-138), em parceria com Susan Stokes e com um sólido defensor minimalista da democracia como Adam Przeworski ${ }^{26}$, é a esse respeito bastante elucidativo. De um lado, após análise exaustiva das possibilidades efetivas de escolha e controle permitidas pelo voto, os autores concluem que as eleições constituem um vínculo de sanção e orientação sobre os representantes particularmente fraco (Manin et al. neste volume: 105-138); de outro, cientes dos custos de um foco centrado exclusivamente no voto, eles 72 aceitam que as "[...] eleições não são o único mecanismo que pode induzir governos a atuar de modo representativo" (Manin et al., 1999: 19; destaque nosso), introduzindo na sua análise a avaliação de eventuais efeitos decorrentes da divisão de poder na estrutura de governo. Os resultados de tal operação, em que também participam outros especialistas (Przeworski et al., 1999), são discrepantes e inconclusivos.

Malgrado a impossibilidade de verificar quaisquer efeitos da divisão de poder na maior capacidade do eleitorado para sancionar ou orientar as ações dos governantes, e plausivelmente com o intuito de evitar eventuais mal-entendidos derivados da ausência de notícias promissoras na sua análise, os autores explicitam seu compromisso com o aprimoramento da democracia: "Esse não é um argumento

26. Para a defesa minimalista da democracia desse autor, ver seu conhecido artigo publicado no mesmo ano do livro em co-autoria com Manin e Stokes (Przeworski, 1999). 
contra a democracia, mas por uma reforma e uma inovação institucional. Nós necessitamos de instituições eleitorais que aumentem a transparência da responsabilidade e facilitem para os cidadãos recompensar ou punir os responsáveis [...] precisamos instituições que forneçam informações independentes sobre o governo [...]”. (Manin et al., neste volume: 133). Também consideram necessária a multiplicação de agências governamentais de controle (accountability agencies), independentes e sujeitas ao controle da população (Manin et al., 1999: 24).

$\mathrm{Na}$ postura dos autores cabe destacar duas questões relevantes quanto à relação entre reforma da democracia, de um lado, e transformações e desempenho da representação política, do outro. Ambas parecem significar de modo emblemático os alcances e impasses das abordagens tradicionais da ciência política - centradas de modo quase exclusivo nas instituições do sistema político - para lidar com a problemática da representatividade das instituições da democracia e com a definição de uma agenda de reforma da democracia preocupada, precisamente, com a abertura de horizontes para a inovação institucional. Simultaneamente, ambas as questões constituem deslocamentos analíticos que sinalizam o espírito do tempo.

Primeiro, no que diz respeito aos deslocamentos e alcances dessas abordagens, amplia-se notavelmente o escopo da representação política para além dos representantes eleitos no legislativo e no executivo, incluindo o controle das funções executivas do governo realizadas pelas burocracias; isto é, a questão da representatividade das instituições democráticas vai além de uma compreensão procedimental minimalista da democracia. Nesse caso, o núcleo normativo mínimo da representação política - o representante deve trabalhar em benefício do representado - expande suas exigências sobre o governo como um todo, não apenas para a relação entre representante eleito e eleitor, apontando para 
um horizonte de reflexão e inovação a respeito de mecanismos de controle e indução outros que não os atrelados às eleições e seus atores - partidos, candidatos e cidadãos. Ademais, e conseqüentemente, sugere-se que a divisão e organização da tomada de decisões - divisão do poder - pode induzir governos a atuarem de modo representativo; divisão, por certo, passível de ser desenhada de modo que se melhore ou se construa representação política. Daí a pertinência de propor agências de prestação de contas independentes.

No que diz respeito aos impasses, e a despeito dos deslocamentos recém-descritos, a reflexão permanece presa às fronteiras das instituições políticas - aparato administrativo e instituições tradicionais de representação política -, e a população continua a comparecer apenas no momento eleitoral. Porém, os dois fenômenos mais notáveis e mais próximos à formação de agentes independentes com capacidade de forçar representantes e burocracias a prestar contas e a 74 se distanciar de modo menos irrefletido das preferências da população têm ocorrido fora dessas instituições políticas e dos organismos governamentais incumbidos de funções de controle horizontal (O’Donnell, 1998). De um lado, a mídia e sua função de vigilância que arrebatou ao mundo da política o controle sobre sua própria visibilidade, conforme mostrado de modo emblemático pela figura do "escândalo" (Thompson, 2002; 1998: 77-108); do outro, a multiplicação de atores societários dedicados ao monitoramento de temas específicos, ora relacionados com interesses e valores difusos como ambientalismo, pacifismo ou combate à corrupção, ora estreitamente vinculados a determinados grupos populacionais como minorias ou segmentos delimitados por áreas de políticas públicas (Fox, 2006; Arato, 2002; Peruzzotti e Smulovitz, 2002; Chalmers, 1997). Isso para não mencionar a onda de reformas participativas que, no hemisfério sul, têm potencializado o protagonismo de atores da sociedade civil, não raro investindo-os juridicamente como 
representantes de determinados segmentos ou interesses da população (Gurza Lavalle et al., 2005; 2006) ${ }^{27}$.

Paradoxalmente, na medida em que ambos os fenômenos ocorrem fora das instituições tradicionais de representação política e das instituições da divisão do poder no Estado, eles permanecem excluídos a priori da reflexão dos autores sobre os fatores institucionais capazes de incidir positivamente na representatividade das instituições democráticas. Embora o diagnóstico de Manin acerca da democracia de públicos aponte para o papel da mídia como instância de mediação que conecta o político com o eleitor de modo individualizado, no seu trabalho com Przeworski e Stokes (1999 e neste volume: 105-138), a mídia como fator capaz de tornar as instituições políticas mais responsivas e passíveis de controle merece apenas atenção ínfima. Por sua vez, não há sequer uma menção ao papel de atores da sociedade civil. De fato, conforme advertido corretamente por Cunil (2002), esses autores assumem de modo indevido que o controle sobre o funcionalismo apenas pode ser efetuado mediante a eleição de políticos, isto é, de forma indireta. Przeworski já foi bastante explícito a esse respeito: há razões "pelas quais não deveríamos nos cegar com essa moda recente (das organizações não-governamentais)", elas representam interesses particulares, não estão sujeitas a controle e tendem a reproduzir a desigualdade de acesso ao sistema político, pois é bem conhecido que se organizam as pessoas possuidoras de recursos (Przeworski, 2002: 81). Entretanto, a proposta do autor é pouco imaginativa: “Afinal, as eleições são o mecanismo mais igualitário de acesso à política. Talvez não sejam efetivas, mas são igua-

27. Para caracterizações dessas reformas destinadas a ampliar o espaço da participação social no hemisfério sul, ver os trabalhos de Grindle (1999), Santos (1998 e 2002b), Pereira e Grau (1988). Como mostrado no trabalho de Gaventa (2004) e de Fung e Wright (2003), as reformas também penetraram o hemisfério norte. 
litárias" (Przeworski, 2002: 81). Se eleições constituem um mecanismo reconhecidamente impotente ou limitado para evitar uma distensão excessiva entre representantes e representados, tal como sustentado por ele e por boa parte da literatura, encerrar o debate acerca do papel da sociedade civil para o funcionamento da democracia argüindo a índole mais igualitária e universalista desses mecanismos resulta uma opção pouco sensível às possibilidades daquilo a que o autor disse visar: a inovação e experimentação institucional para a reforma da democracia.

\section{Democracia participativa: e a representação?}

A exploração analítica de horizontes de experimentação institucional para a reforma da democracia tem sido preocupação muito mais incisiva e persistente em outra constelação de autores e agendas de pesquisa, em geral não centrados nas instituições políticas, mas nas capacidades de influência e

76 racionalização da sociedade sobre o poder político. Os esforços por identificar expedientes capazes de moldar os conteúdos produzidos pelas instituições da democracia de modo que se tornem mais próximos dos anseios e necessidades da população têm perfilado distintas agendas de pesquisa atreladas a um núcleo comum: o aprofundamento da democracia ou, se se quer de maneira altissonante, a democratização de democracia (Santos, 2002). De certa forma, essas agendas debruçam-se sobre uma problemática delimitada por duas grandes balizas: de um lado, o abandono das utopias revolucionárias e a convicção normativa do valor da democracia como marco institucional para processar a mudança social; do outro, a crítica ao domínio das compreensões meramente institucionais da democracia e o empenho de reintroduzir questões substantivas no campo da teoria democrática.

As literaturas voltadas para a elucidação teórica e empírica do aprofundamento da democracia têm investido suas energias principalmente em três flancos com sobreposições 
amplas: na participação da população, na sociedade civil e na última geração de inovações institucionais que, promovidas pelo mundo afora, visam a acolher diversas formas de participação em arcabouços institucionais de desenho e implementação de políticas públicas. Nos três casos, é claro, há uma perspectiva societária ou uma aposta nas potencialidades de controle e transformação gradual de "baixo para cima". Assim, as inovações institucionais são pensadas, normalmente, a partir das perspectivas analíticas da participação e da sociedade civil.

Curiosamente, essas agendas centradas em dinâmicas societárias para pensar a reforma da democracia têm prestado pouca ou nenhuma atenção às transformações da representação, e, em geral, têm- lhes passado desapercebido o papel dos atores da sociedade civil enquanto atores que realizam funções de representação política. Isso, a despeito de as inovações institucionais participativas terem estimulado, na prática, o engajamento de diferentes atores da sociedade civil, cuja participação (representando alguém) não raro é juridicamente estatuída em termos de representação (Houtzager et al., 2004). A despeito da complementaridade entre participação e representação - pelo menos em compreensões não extremas do valor da participação, a ausência da segunda problemática nesses debates é sistemática a ponto de causar espanto ${ }^{28}$. São raras as exceções que têm formulado explicitamente uma conexão entre transformações da representação e novas funções políticas de representação assumidas por atores societários ${ }^{29}$.

\footnotetext{
28. Ver notas 18 e 19.

29. Ver os trabalhos publicados em Chalmers e Vilas (1997), particularmente o capítulo do próprio Chalmers et al. ver também Raichelis (2000: 201-270), Houtzager et al. (2002), Friedman e Hochstetler (2002) e Gurza Lavalle et al. (2004, 2005 e 2006). A filosofia política normativa também tem produzido trabalhos particularmente interessantes; ver, por exemplo, Young (2002 e neste volume: 139-190) e Urbinati (1999 e neste volume: 190-228).
} 
Diversos motivos podem animar esse descuido. Quiçá o fato de a representação política estar atrelada historicamente às instituições político-eleitorais tenha induzido certa cautela ou hermetismo de abordagens centradas em uma perspectiva societária. Difícil não reparar, de outro lado, que a questão da representação introduz interrogações espinhosas acerca da representatividade dos atores da sociedade civil, pelo que, evitar a primeira, por certo, permite esquivar as segundas. Seja como for, os motivos que aqui interessam são de caráter conceitual, isto é, dizem respeito aos custos cognitivos em maior ou menor medida associados a determinadas escolhas analíticas; especificamente, à idéia de participação, e a certa compreensão da idéia de sociedade civil altamente estilizada e unificadora.

Sociedade civil e participação aparecem como elementos-chave em agendas diversas de reforma da democracia como, por exemplo, aquelas do aprofundamento da demo78 cracia (deepening democracy), da transparência e controle social das instituições políticas (social accountability), do fortalecimento da capacidade de ação e participação da sociedade na gestão pública (empowered participation), da democracia deliberativa e, é claro, nas literaturas da democracia participativa e da própria sociedade civil ${ }^{30}$. Obviamente,

\footnotetext{
30. Para a literatura de aprofundamento da democracia (deepening democracy), ver os trabalhos de Heller (2001 e no prelo), Fung (2004), Fung e Wright (2003), e Santos (2002b); para as abordagens de transparência e controles sociais das instituições políticas (social accountability), ver Arato (2002), Peruzotti e Smulovitz (2002); para o enfoque de fortalecimento da capacidade de ação e participação da sociedade na gestão pública (empowered participation), ver Fung e Wright (2003); para a perspectiva da democracia deliberativa, ver Habermas (1993, 1995 e 1998), Gutmann e Thompson (2004), e os trabalhos em Bohnman e Rehg (2002) e em Elster (1998). A literatura da sociedade civil é muito maior e, por vezes, também associada a críticas radicais da democracia (v. gr. Keane, 1992), mas aqui remete fundamentalmente ao trabalho de Cohen e Arato (1992), e de acadêmicos vinculados a essa perspectiva na América Latina como Avritzer (1994, 1997), Olvera (2003), Panfichi (2003). Ainda dentro da literatura da sociedade civil, mas em perspectiva habermasiana, também os trabalhos dos anos 1990 de Costa (2002).
} 
existem diferenças de ênfases, focos e distinções analíticas nessas agendas; todavia, é fácil identificar traços compartilhados que, conectados à idéia de participação e a certa compreensão da sociedade civil, exercem efeitos de bloqueio sobre a possibilidade de se conceber a ação dos atores societários e as dinâmicas participativas em termos de representação política.

Primeiro, as agendas voltadas para a reforma da democracia descansam, em maior ou menor medida, em concepções estilizadas e unificadoras da sociedade civil, não raro obliterando tanto diferenças internas relevantes no terreno dos atores societários quanto interações presentes nas interfaces entre as instituições políticas e tais atores ${ }^{31}$. Nessa concepção, a sociedade civil, revigorada em diversos contextos regionais do mundo no último quartel do século $\mathrm{XX}$, compareceria ao encontro com o Estado como agente de racionalização da ação pública e de democratização das decisões políticas; agente que, por sinal, estaria guiado de modo dialógico e com capacidades e convicções previamente definidas porque emanadas do seu arraigo genuíno no

De alguma forma, também o trabalho mais recente de Avritzer (2003), centrado na idéia de públicos participativos.

31. A hiper-simplificação da relação entre atores societários e as instituições políticas encontra origem em uma constelação de fatores, mas pela sua influência notável cabe mencionar tanto a teoria de Habermas (1987) da sociedade em dois níveis - o nível sistêmico e o mundo da vida -, reapropriada com nuances importantes por Cohen e Arato (1992) na sua teoria da sociedade civil, quanto a origem diretamente política e de oposição ao Estado do ressurgimento da idéia de sociedade civil na Europa do Leste e na América Latina. No Brasil, tal hiper-simplificação veio acompanhada do esforço de reespecificação conceitual da categoria sociedade civil que caracterizou o debate dos anos 1990. Para um balaço crítico desse esforço, ver Gurza Lavalle (2003a). Análises alicerçadas em outros referenciais teóricos têm sugerido, no país, interpretações mais interessantes da relação entre Estado e atores societários - sejam esses referenciais próprios à ótica dos novos movimentos sociais (Sader, 1988); tocquevillianos (Boschi, 1987), gramscianos (Dagnino, 1998-1999), ou de outras vertentes analíticas (Landim, 1998; Fernandes, 2002). Para uma análise das famílias de argumentos da sociedade civil, centrada na relação Estado/sociedade, ver Gurza Lavalle (1999). 
tecido social. Introduz-se, assim, o pressuposto de uma certa continuidade ou conexão natural entre um bloco de atores societários e a sociedade ou alguns segmentos dela - isto é, entre sociedade civil e sociedade -, tornando descabidas indagações acerca dos processos de representação que vinculam ambos. Basta lembrar a esse respeito, com Pitkin (1967: 60-91), que representação, por definição, supõe diferença e distância, não identidade e coincidência, entre a representação e aquilo que é representado.

Segundo, as agendas de pesquisa e de intervenção voltadas para a reforma da democracia se encontram fortemente atreladas à idéia de participação, ora como presença direta das pessoas eventualmente afetadas ou beneficiadas por decisões públicas, ora como deliberação face-a-face. A participação de grupos e camadas da população tidas como sub ou mal-representadas nos lócus da representação política constituiria, assim, expediente-chave a estimular o 80 melhor funcionamento das instituições políticas. De fato, para parte substancial da literatura a diferença crucial entre participação de cidadãos e participação de associações tem passado desapercebida, ocultando a problemática da representação inerente ao segundo tipo de participação ${ }^{32}$. Se, às vezes, a própria idéia de participação parece sobrecarregada de expectativas quanto aos seus eventuais efeitos positivos para aprimorar a qualidade da democracia ${ }^{33}$, ela também revela-se cognitivamente empobrecedora quanto à possibilidade de se pensar na representação. A participação supõe

32. Para uma crítica à ausência de tal distinção na literatura ver Houtzager et al. (2003 e 2004)

33. Como mostrado em argumentação minuciosa por Cunill (1997: 71-195), a participação não conta em si com quaisquer garantias quanto à realização das virtualidades positivas não raro a ela atribuídas na literatura; mais, corre-se o risco de reintroduzir e aprofundar aquilo que se procurava resolver: despolitização, desigualdade e déficit de legitimidade. Para uma amostra de quanto a participação tem se tornado um credo pouco reflexivo ver Klinksberg (2000). 
o envolvimento direto ou a presença do sujeito dessa participação - indivíduos, cidadãos, trabalhadores -, enquanto a representação, no melhor dos casos, é um momento posterior à participação, do qual ficam incumbidas instituições de agregação. Assim, uma vez assumido o registro da participação, para se pensar no aprimoramento das conexões entre instituições políticas e dinâmicas societárias, tornamse carentes de sentido perguntas acerca da representação exercida por atores societários. Afinal, conforme já advertido, participação é auto-apresentação, enquanto representação remete ao ato de tornar presente por intermédio de outrem algo ou alguém ausente (Pitkin, 1967: 8-9).

A força dos efeitos de bloqueio derivados dessas duas escolhas analíticas torna-se patente se considerado o quanto dinâmicas de representação política estão presentes em fenômenos normalmente estudados, pelas agendas de aprofundamento da democracia, sob a ótica da participação. Breve exemplo permitirá mostrar com eloqüência a questão. Em diversos países, mudanças favoráveis à introdução de controles sociais na gestão pública têm aberto novos canais de participação a cidadãos e de representação política a atores societários, embora tal representação raramente seja examinada enquanto tal. O Brasil tornou-se referência do debate internacional acerca do aprofundamento da reforma da democracia, precisamente, graças à onda de novas experiências participativas na definição de prioridades ou no desenho de políticas públicas, enquadradas inicialmente na Constituição de 1988 ou em administrações municipais sob o comando do Partido dos Trabalhadores, notadamente conselhos gestores e orçamento participativo ${ }^{34}$. Os conselhos, consagrados na Constituição, contam com atribuições orça-

34. Exemplos da presença dessas experiências no debate internacional voltado para a reforma da democracia são Heller (2001), Isaac (2002), Fung e Wright (2003) e Santos Boaventura (2002a; 1998). 
mentárias para financiar projetos e implementar suas próprias decisões; no entanto, na estrutura federativa compete aos executivos federal, estaduais e municipais, bem como ao Congresso, às Assembléias legislativas e às Câmaras de Vereadores, sancionar as peças orçamentárias anuais. Assim, as inovações institucionais participativas e sua regulamentação instituíram princípios e funções concorrentes de representação política, suscitando conflitos quando - como acontece com freqüência e largueza - as propostas dos conselhos são modificadas pelos poderes executivo e legislativo ${ }^{35}$.

Nos conflitos entre representantes, ou seja, entre conselheiros e legisladores, ambas as partes contam com legitimidade própria, emanada ora das urnas, ora dos processos de escolha - inclusive eleições - definidos pelas respectivas leis de criação dos conselhos. Ainda que em proporções e com abrangência muito diferentes, também em ambos os casos a determinação de prioridades orçamentárias faz 82 parte das atribuições legais que delimitam o âmbito e competências da representação legalmente instituída. O conflito legalmente instituído entre princípios de representação evidencia, para dizê-lo com Dagnino (2002: 290-293), o quanto os sentidos tradicionais da representação política aparecem sistematicamente deslocados. Por outras palavras, os processos de transformação da representação política vivenciados no país nos últimos anos transbordaram parcialmente as fronteiras das eleições, enveredando para o controle e representação sociais nas funções executivas

35. Tal foi o caso do conflito entre a o Conselho de Direitos da Criança e do Adolescente (CDCA) e a Câmara de Vereadores do município de São Paulo, quando da sessão plenária em que seria aprovada a Lei Orçamentária de 2002. A mobilização popular e pressão exercida pelos conselheiros sobre a Câmara objetivavam impedir que os vereadores emendassem o orçamento proposto pelo Conselho. No ano anterior, os 73 milhões de reais aprovados pelo Conselho para o financiamento de projetos foram reduzidos à modesta cifra de 5 milhões de reais no Projeto de Lei Orçamentária aprovado na Câmara (Gomes da Silva, 2003: 90-98). 
do governo, especificamente em determinadas áreas de políticas públicas. Nesse deslocamento, os atores societários desempenham, de facto, funções de representação política consagradas de jure, embora permaneçam incógnitas acerca dos eventuais critérios que alicerçam a legitimidade dessas funções.

A despeito de conflitos semelhantes se multiplicarem (Gomes da Silva, 2003; Laisner, 2005), são literalmente excepcionais os estudos que, se desvencilhando do registro da participação e contornando seus custos cognitivos, vislumbram o papel de representação política exercido pelos atores societários com cadeira nos conselhos e levantam questões acerca dos dilemas da representatividade enfrentados por esses atores e pelos próprios conselhos (v. gr. Pinto, 2004) ${ }^{36}$. Parece óbvio que a representação política realizada por atores societários constitui fronteira crítica para pensar a reforma da democracia, e, por conseguinte, para o debate contemporâneo travado pelas literaturas voltadas para o aprofundamento da democracia; contudo, e embora por motivos diferentes aos da literatura da reconfiguração da representação, tais literaturas são pouco propícias para refletir nas funções de representação política exercida, precisamente, por atores da sociedade civil.

\section{Representação virtual, pluralização e diversificação}

Há dois fenômenos no processo de transformação da representação que não parecem passíveis de compreensão cabal, do ponto de vista das suas conseqüências para a democracia, se restritos analiticamente apenas a um reor-

36. As ênfases comuns na literatura de conselhos estão animadas por modelos de teoria participativa ou deliberativa, daí que a tônica dominante seja a análise das condições adequadas para uma participação e deliberação eqüitativas. A esse respeito ver o balanço elucidativo de Tatagiba (2002). Para uma exceção interessante que atentou para a questão da representação, ver Raichelis (2000: 201-270). 
denamento de elementos próprios às instituições clássicas da representação política. Tampouco é possível explorálos satisfatoriamente a partir de propostas de reforma da democracia centradas na idéia de democracia participativa. O primeiro é a emergência de novas instâncias de mediação entre representantes e representados: a mídia, é claro, mas não só, também constelações de atores intermediários não mais ordenáveis pelas grandes clivagens ideológicas e socioeconômicas das democracias de partidos de massas e suas grandes centrais sindicais. O segundo, mais recente e com interfaces com o primeiro, é a multiplicação de instâncias de participação cidadã e de representação coletiva incumbidas da definição de prioridades públicas e do desenho e supervisão de políticas. À margem da centralidade adquirida pela mídia - que exigiria uma análise específica -, na interseção entre esses dois fenômenos, ou seja, entre a proliferação de atores societários e a abertura de espaços 84 participativos, vêm ocorrendo processos inéditos de experimentação institucional que iluminam o horizonte de reforma da democracia, apontando para a pluralização dos atores com investidura própria ao desempenho de funções de representação política, e para a diversificação do lócus em que ela é exercida ${ }^{37}$.

Novos mediadores estão a exercer de facto e de jure funções de representação política em novos lugares de representação ${ }^{38}$. Em latitudes as mais diversas, atores coletivos

37. A pluralização dos atores e a diversificação do lócus da representação parecem se inscrever em uma tendência mais ampla de policentrismo (ver Houtzager, 2003).

38. Parte importante desses agentes corresponde ao conceito "grupos de interesse", e a abordagem pluralista na ciência política têm-nos abordado de modo amplo e competente (Dahl, 1982). Por sua vez, Schimmiter (1992), na sua formulação do conceito "regimes parciais de representação", incorporou tais grupos como uma peça-chave na representação de interesses das democracias contemporâneas. A análise de ambos os conceitos escapa do foco deste artigo, e não há espaço nesta nota para tanto. 
têm demandado e/ou Governos têm proposto e passado leis destinadas a ampliar os mecanismos de democracia direta - iniciativa popular, referendum, plebiscitos - e a introduzir a participação de atores (representantes) da sociedade civil nos processos de formulação de políticas ${ }^{39}$. Aqui e alhures, com alcances e efeitos diferentes, esses atores têm ampliado consideravelmente sua capacidade de interlocução com governos subnacionais e nacionais, bem como com agências multilaterais e organizações internacionais. Para além da diversidade de países em que ele ocorre, a importância desse fenômeno vem à tona quando observado, na sua institucionalização parcial e da perspectiva da reforma da democracia, como uma composição de diversos lugares ou pisos de representação que prefiguram traços de uma democracia e representação política pós-liberais, para dizê-lo com Schmitter (2005). Pós-liberais não porque orientadas a substituir os partidos como instâncias de mediação entre representantes e representados, nem o voto como mecanismo de autorização e sanção, mas porque a pluralização e diversificação da representação a levam aonde as eleições e seus atores acusam limites estruturais ${ }^{40}$ - notadamente o controle sobre as burocracias e a representação coletiva ou de grupos sem expressão numérica suficiente para pesarem na lógica da política eleitoral.

Com maior precisão, a representação exercida por atores da sociedade civil é coletiva e ocorre através de um conglomerado heterogêneo de organizações civis que atuam em nome de subpúblicos e/ou minicomunidades, diferindo da representação de interesses pessoais ou de indivíduos, própria da democracia liberal, sem corresponder, no extremo oposto, com a representação do bem comum ou

39. Ver nota 27.

40. Conforme mostrado na seção 2 deste artigo. 
da nação, característica da tradição republicana e de compreensões não liberais da própria representação e dos interesses mediante ela salvaguardáveis (Pitkin, 1967: 168-208). Sem dúvida, os sindicatos são o exemplo mais notável de representação de grupo ao longo do século XX, mas pouco ou nada coincidem com o fenômeno de diversificação do lócus e pluralização dos atores da representação política acontecido nos últimos anos: em vez de uma negociação entre agentes privados no mercado (empregador e empregado), mediada pela legislação trabalhista (Estado) e, quando necessário, por instâncias de arbitragem, a representação é efetuada principalmente junto aos órgãos decisórios - executivos - do Estado $^{41}$; em vez de um modelo organizativo único (sindicato), munido com especificações quanto ao vínculo com os representados (filiação) e aos dispositivos de prestação de contas e sanção (eleições internas, desfiliação), as entidades civis possuem formatos organizacionais 86 os mais variados e relações com seus públicos nem sempre explícitas ou claras, por vezes, apenas simbólicas.

Assim, a representação coletiva tornou-se eminentemente heterogênea quanto aos interesses representados, às formas organizacionais dos atores, ao lócus dentro do Estado, e às jurisdições, instâncias e formas de institucionalizá-la. A despeito de a pluralização e diversificação da representação virem acompanhadas de tal heterogeneidade, os potenciais da representação coletiva localizam-se em posição clara no espectro de possibilidades que vai do mandato imperativo do direito privado à autonomia do representante e lassidão dos seus vínculos com o representado

41. É claro que os sindicatos realizaram e continuam a realizar funções de representação perante o Estado, por exemplo, para pressionar pelo aumento do salário mínimo ou em contextos de corporativismo de Estado; contudo, atenta-se aqui apenas para a inexistência de uma negociação entre partes privadas no caso dos novos espaços e atores da representação. 
- próprios da democracia representativa ${ }^{42}$. A existência de representação no interior da sociedade civil, como contrato entre partes privadas, carece de qualquer novidade. Afinal, a representação é oriunda do direito civil. A novidade estriba na emergência de formas de representação política - no sentido mais estrito da palavra - exercidas por organizações civis; formas constituídas de modo inexorável pela dualidade entre representação e representatividade, entre representante e representado. Contudo, as modalidades de representação coletiva em questão não se encontram submetidas aos limites estruturais das eleições e dos eleitos, impostos pela sua dupla função de representação perante o poder, visando a regulá-lo socialmente, e de representação no poder, comprometida com governar e impor obediência sobre a população, se for preciso. Seus limites são outros, mas nesse aspecto, a representação coletiva é, no fundamental, pressão, controle, supervisão, intervenção, assédio e reclamo perante o poder em instâncias executivas de políticas e em espaços de interlocução. Mais: em se tratando de representação em relação a políticas publicas especificas, e em nome de subpúblicos e/ou minicomunidades - e não da nação ou de um eleitorado portador de mandato vago composto pela agregação de votos -, há condições mais favoráveis para a consonância entre a orientação de decisões dos representantes e as preferências dos representados.

Porém, malgrado existam diversos elementos que sugerem o potencial de representatividade da representação coletiva como um expediente de reforma da democracia, sua problematização teórica e sua defesa pública esbarram em limites evidentes, a saber, a ausência de mecanismos generalizados, formais e estáveis de ordenação da relação

42. Conforme analisado na segunda seção deste artigo. 
entre atores da sociedade civil e seus públicos, beneficiários ou comunidades - notadamente mecanismos de autorização, prestação de contas, responsividade e sanção ${ }^{43}$. Conforme argumentado ao longo destas páginas, a inexistência de modelos consagrados histórica ou analiticamente para problematizar a emergência de instâncias societárias de intermediação em termos de representação propriamente política subjaz em boa medida à desatenção das literaturas competentes. Ainda assim, e a despeito da ausência de mecanismos claros de conexão entre organizações civis e subpúblicos, as experiências de pluralização dos atores e de diversificação do lócus da representação se avultam a olho nu.

Assim, é pertinente buscar uma perspectiva analítica que permita elaborar o papel inédito da representação coletiva conjugando uma tríplice operação: primeiro, preservar o núcleo normativo mínimo da representação - atuar em favor do representado; segundo, não aplicar crité88 rios de avaliação que condenem a priori as novas práticas de representação à ilegitimidade - em definitivo, organizações civis não são nem podem agir como partidos políticos; terceiro, examinar essas práticas contra o pano de fundo da reforma da democracia a partir dos seus efeitos de inclusão política, sem suspender, todavia, as exigências normativas próprias de toda representação política democrática, o que inclui dispositivos de expressão de preferências e sanção sobre o representado.

O pensamento de Edmund Burke oferece perspectivas interessantes para avançar na revisão do conceito de representação de modo a alargar suas fronteiras conforme esboçado acima. Segundo afirmara Burke (1942 [1774]), o

43. Por exemplo, apenas uma minoria dos atores da sociedade civil define seus públicos ou beneficiários como membros; categoria que, em princípio, implicaria a existência de mecanismos de sanção característicos das relações da afiliação notadamente, o direito de saída. 
melhor dispositivo para garantir a autenticidade da representação - sua representatividade - seria a existência de um compromisso representativo genuíno; entrementes, dada a contingência desse componente subjetivo, a introdução de mecanismos institucionais formais tornava-se iniludível e desejável. A presunção de representar alguém, é claro, não equivale à sua efetiva representação; no entanto, o comprometimento com os interesses representados é um componente vital da representação, irredutível a dispositivos institucionais. Embora a dimensão subjetiva da representação tenha sido sistematicamente desvalorizada no campo das teorias da democracia, como apontado por Sartori em reconhecimento à arguta intuição de Burke quanto à importância dessa dimensão, as regras e desenhos institucionais tornam-se impotentes quando os representantes não são animados ou comovidos por um "sentimento de representação" - idem sentire, animus (Sartori, 1962). De modo mais preciso, se a representação é irredutível à mera representação presuntiva, a representatividade não pode prescindir do compromisso de representar. Aliás, não é descabido esperar que esse compromisso tenda a se manifestar com maior intensidade nas formas de representação coletiva do que no comportamento de partidos no parlamento.

"Sentimento" ou "compromisso" de representar alguém aludem àquilo que Burke (1792), nas suas dissertações epistolares clássicas, denominara de representação virtual ${ }^{44}$. "Virtual" na acepção precisa guardada na língua inglesa para o termo, isto é, como "algo que é tal em essência ou efeitos, embora não formalmente reconhecido ou acei-

44. Nas palavras de Burke (1792), "Representação virtual é aquela em que há comunhão de interesses e empatia de sentimentos e desejos entre aqueles que atuam em nome de quaisquer pessoas e as pessoas em nome das quais eles atuam - embora os primeiros (fiduciários) não tenham sido, de fato, escolhidos pelos segundos". 
to" ${ }^{45}$. A idéia traz consigo certo ranço conservador devido à biografia política do seu criador e a ter sido invocada, na história dos embates políticos pela expansão do sufrágio, como argumento contrário ao voto feminino ou à inclusão no parlamento de circunscrições territoriais desprovidas de representação; contudo, ela desempenhava um papel complexo na doutrina burkiana da representação e foi utilizada pelo próprio autor para defender a extensão do voto, nos casos das colônias americanas e dos católicos na Irlanda, bem como nos casos menos conhecidos de Wales, Chester e Durham (Burke 1792; Pitkin, 1967: 168-189).

De fato, a lógica interna da idéia de representação virtual é de inclusão política e não de exclusão, embora essa lógica permita invocar a existência ou inexistência de representação virtual para denegar ou defender a ampliação do sufrágio. Se uma localidade dedicada à agricultura podia ser representada no parlamento, graças à empatia e à comu90 nidade de interesses, por outra localidade com vocação econômica agrícola - daí a irrelevância de ampliar o sufrágio visto que os interesses objetivos ${ }^{46}$ estavam representados de modo virtual -, pretensão semelhante tornava-se absurda no caso da questão católica na Irlanda e da questão colonial. Nesses casos, inexistiam quaisquer suportes na composição e formação da representação política "real" nos respectivos parlamentos para imaginar possível a representação virtual dos interesses objetivos das correspondentes populações

\footnotetext{
45. Conforme definido no Webster's Dictionary. "Representação virtual" é conceito consagrado no campo das teorias da representação política, e nelas permanece, embora o substantivo "virtual" tenha sido resemantizado na onda mais recente de expansão das tecnologias digitais. Contrariamente ao sentido do conceito, nas línguas neolatinas o substantivo costuma ser intuitivamente entendido como algo limitado a efeitos potenciais, mas não reais.

46. Burke sustentava uma compreensão objetiva e impessoal de interesses: os interesses da indústria, do comércio ou, inclusive, dada sua condição de exclusão, os interesses das colônias ou dos irlandeses.
} 
excluídas; por isso, o único caminho possível era a instauração de uma representação efetiva ${ }^{47}$.

O elo entre representação virtual e inclusão política resulta peculiarmente pertinente e atual, em especial, se levadas em consideração sua sintonia com os debates sobre minorias e aprofundamento da democracia, bem como sua semelhança com os usos contemporâneos da idéia mais ampla de advocacy - argüir em favor de algo ou alguém, defender mediante argumento, recomendar a adesão ativa de uma causa, justificar publicamente o valor de algo ou alguém ${ }^{48}$. Em tais usos, ad-vocare implica tanto a idéia de chamar para si o interesse de algo ou alguém quanto a ação de vocalizar ou dar voz a esse interesse. É bastante conhecido que atividades de advocacy têm sido utilizadas de longa data como expediente para a defesa de interesses difusos, de minorias e de camadas mal-aquinhoadas da população (Seidle, 1993). No contexto das transformações aqui analisadas, todavia, tais atividades passaram a se vincular a práticas de representação e a ser pensadas de modo explícito como exercício de uma representação por advocacy (Imig, 2002; Sorj, 2005); isto é, de uma representação destinada a dar voz - algo distinto da função de ser porta-voz própria de práticas de representação coletiva englobadas claramente na idéia de grupos de interesse. O protagonismo adquirido por atores da sociedade civil mediante o trabalho de advocacy compreende, mas dista de se reduzir à vocalização difusa de causas diversas, antes, desempenha também funções de intermediação perante o poder público na forma de representação virtual, ou seja, da defesa de interesses

47. Os usos excludentes da idéia de representação virtual perderam legitimidade no processo de massificação das democracias e de consolidação da compreensão liberal da representação (para a concepção liberal ver Pitkin, 1967: 190-208; e neste volume [1989]: 15-47).

48. Conforme o Black's Law Dictionary. 
que não autorizaram essa defesa ou que, embora simpáticos a ela, carecem de qualquer mecanismo estável para controlá-la ou comunicar-lhe preferências.

O valor dessas práticas, quando olhadas do prisma da representação virtual ou da representação por advocacy, é se tornarem porta-vozes de demandas de segmentos da sociedade, temas e interesses mal ou sub-representados nos circuitos tradicionais da representação política, ora por se tratar de domínios de decisão muito específicos, como acontece em determinadas áreas e subáreas de políticas públicas, ora por se tratar de minorias ou de grupos particularmente desprovidos de recursos econômicos, políticos e culturais, ou inclusive por se tratar de temas e problemas emergentes negligenciados pelos atores tradicionais da representação. É verdade que não mais é possível sustentar, como feito por Burke (e depois por diversos estruturalismos), a existência de interesses objetivos aos quais as pessoas estariam adscri92 tas e cuja concretude permitiria sua representação obviando quaisquer procedimentos de consulta; entretanto, a representação coletiva, mesmo se virtual, diz respeito a questões cuja proximidade com o representado reduz consideravelmente o problema da ausência de interesses articulados em preferências, de opiniões ou inclusive de perspectivas, capazes de orientar as decisões do representante ${ }^{49}$.

Seria ingênuo reputar que qualquer prática de representação unilateral constitui representação virtual no sentido burkiano - compromisso representativo "genuíno" -, ou que todo compromisso representativo é igualmente compatível com exigências democráticas. Sem dúvida, no interior da sociedade civil há noções e práticas de representação irreconciliáveis com exigências democráticas, bem como outras plenamente compatíveis com tais exigências, mas

49. Para a diferença entre representar interesses, opiniões ou perspectivas, ver o trabalho de Young neste volume. 
isso é uma questão empírica que deve ser resolvida no plano da pesquisa (ver Gurza Lavalle et al., 2006; 2005). Não obstante, ante os limites estruturais do mecanismo eleitoral para estimular a representatividade das instituições democráticas, a representação virtual é sem dúvida um caminho de experimentação possível para corrigir parcialmente vieses sistemáticos de exclusão de determinados segmentos da população. Nesse sentido, não é difícil perceber que o componente subjetivo da representação virtual subjaz em boa parte do debate sobre a inclusão política de minorias pela via de cotas para representação identitária, ou melhor, da política da diferença (Young, 2002, e, neste volume: 139-190).

Contudo, não é possível negligenciar que permanecem em pé os limites da representação virtual quando julgada pela sua incompatibilidade com exigências democráticas relacionadas à presença de mecanismos de prestação de contas e sanção. A representação política consagrada nas democracias de massas é produto de longa história em que as pressões pela ampliação do sufrágio levaram à ruína os expedientes personalistas de conexão entre representante e representado característicos da democracia parlamentar oitocentista; expedientes plutocráticos porque ancorados na proximidade social dos partícipes de uma democracia restrita às camadas abastadas da população. A democracia de partidos introduziu novas mediações entre eleitor e eleito, e a conexão entre ambos passou a ser intercedida por burocracias partidárias. Os representados perderam qualquer controle direto sobre o representante, mas cresceram em número e se utilizaram da obediência partidária e do perfil programático dos partidos para introduzir sanções e preferências no jogo eleitoral. Com o tempo, as pressões sociais pela ampliação da democracia foram além do voto e se instalaram na vida interna dos partidos. Algo semelhante ocorreu na história do sindicalismo, os embates pela representatividade se seguiram à consolidação do papel dos sin- 
dicatos como representantes legítimos da força-de-trabalho. Visto que a pluralização de atores de representação coletiva em instâncias diversas constitui um fenômeno inédito em plena efervescência, ainda em processo de institucionalização, não parece descabido esperar que sua importância crescente venha acompanhada de pressões para tornar essas práticas compatíveis com exigências democráticas mínimas de responsividade, prestação de contas e sanção. De fato, a multiplicação de iniciativas e legislações para regular as atividades de entidades privadas sem fins lucrativos ocorridas no hemisfério sul, é um movimento que aponta nessa direção.

O quanto é possível reformar a democracia mediante modalidades de representação animadas, pelo menos em parte, pela lógica da representação virtual, é uma questão cujo equacionamento parece possível apenas se o caminho da experimentação prática for percorrido e se a reflexão for desimpedida de problematizar tais modalidades em termos 94 de representação política - o que passa, evidentemente, pela compreensão e avaliação dos mecanismos de controle e sanção nelas presentes. De um lado, representação virtual é melhor do que ausência completa de representação e, nesse plano, ela é um instrumento de inclusão política. Nela, há mecanismos indiretos de prestação de contas e sanção que precisam ser estudados e avaliados quanto à sua capacidade de induzir responsividade virtual - quer dizer, responsividade em essência ou de fato, embora não formalmente reconhecida ${ }^{50}$. De outro, conforme ocorreu em epi-

\footnotetext{
50. Cumpre notar que, para Burke, a representação virtual apenas existe quando o representante atua de fato em benefício de interesses objetivos que coincidem com o perfil de determinada localidade sem membros no parlamento, cujos habitantes são assim beneficiados por um representante virtual. Nesse sentido, a representação virtual burkiana é sempre substantiva ou efetiva, pois ninguém pode ser não-representado ou mal-representado virtualmente. Contudo, sugere-se aqui que a possibilidade de se pensar em uma responsividade virtual, cuja peculiaridade reside no caráter indireto dos mecanismos capazes de gerá-la.
} 
sódios históricos anteriores, mecanismos de conexão entre representante e representado são passíveis de introdução e alteração com o tempo. A esse respeito, práticas de representação virtual podem se transformar em distintas modalidades de representação política "real", se a envergadura por elas atingida as tornar objeto de pressão da sociedade, dos seus públicos, do Estado e dos seus próprios atores.

\section{Adrián Gurza Lavalle}

é professor do Departamento de Política da Pontifícia Universidade Católica de São Paulo (PUC) e pesquisador do Centro Brasileiro de Análise e Planejamento (Cebrap)

\section{Peter P. Houtzager}

é pesquisador do Institute of Development Studies (IDS), Sussex University

\section{Graziela Castello}

é assistente de pesquisa no Cebrap e mestranda em Ciência Política do IFCH/ Unicamp.

\section{Bibliografia}

ABAL MEDINA, Juan Manuel. 1996. "El camino hacia la democracia pos representativa”. PostData, n. ${ }^{\circ} 2$.

ARATO, Andrew. 2002. "Representação, soberania popular e accountability". Lua Nova, CEDEC, n. ${ }^{\circ}$ 55/56 - Cenários de Direitos.

ARAUJO, Cicero. 2000. "República e democracia". Lua Nova, CEDEC, n. ${ }^{\circ} 51$. ARROW, Kenneth. 1970. Social choice and individual values. (1951) New Haven: Yale University Press.

AVRITZER, Leonardo. 1994. "Modelos de sociedade civil: uma análise específica do Caso Brasileiro”. In: (coord.). Sociedade civil e democratização, Belo Horizonte: Del Rey. . 1997. "Um desenho institucional para o novo associativismo". Lua Nova, CEDEC, n. ${ }^{\circ} 39$. 2003. Democracy and the Public Space in Latin America. Princeton: Princeton University Press. 
BOBBI0, Norberto. 2000. O futuro da democracia. (1984). Rio de Janeiro: Paz e Terra.

BOHAM, James; WILLIAM, Rehg. 2002. Deliberative democracy. Massachusetts: MIT Press.

BOSCHI, Renato. 1987. A arte da Associação. Rio de Janeiro, Vértice.

BOURDIEU, Pierre. 1987. "La delegación y el fetichismo político". In: Cosas dichas. Barcelona: Gedisa.

BURKE, Edmund. 1942. "Carta a los electores de Bristol". (1774) In: Textos políticos. México: Fondo de Cultura Económica. . (1792). "An Extract from Letter to Sir Hercules Langrishe, on the Subject of the Roman Catholics of Ireland”. Disponível em: http//www.ourcivilisation.com/smartboard/shop/burke/extracts/ chap18. htm.

CAMPILONGO, Fernandes Celso. 1988. Representação política. São Paulo: Ática. CERVELLINI, Silvia. 2000. "Marketing político e marketing comercial: uma reflexão”. In: FIGUEIRED0, Rubens (Org.). Marketing político e persuasão eleitoral. Rio de Janeiro: Fundação Konrad Adenauer.

CHALMERS, Douglas A. Martin, SCOTT B. PISTER, Kerianne. 1997. “Associative Networks: New Structures of Representation for the Popular Sectors?". In: , Vilas, Carlos M. et al. The New Politics of Inequality in Latin America. Rethinking Participation and Representation. Oxford: Oxford University Press.

e VILAS, Carlos M. (eds). 1997. The New Politics of Inequality in Latin America. Rethinking Participation and Representation. Oxford: Oxfors University Press.

COHEN, Jean e ARATO Andrew. 1992. Civil Society and political theory. Massachusetts: MIT.

CONDORCET, Marquis de. 2003. Essay on the Application of Analysis to the Probability of Majority Decisions. (1785). Selected excerpts in Dahl, Shapiro e Cheibub. The democracy sourcebook. Cambridge: MIT Press.

COSTA, Sérgio. 2002. As cores de Ercília: Esfera Pública, democracia, configurações pós-nacionais. Belo Horizonte: UFMG.

CUNIL, Grau Nuria. 1997. Pensando lo público a traves de la sociedad: nuevas formas de gestión pública e representación social. Caracas: Nueva Sociedad/ Clad.

2002. "Nudos críticos de la accountability social.

Extrayendo lecciones de su institucionalización en América Latina”. In: Peruzzotti, Enrique e Smulovitz, Catalina. Controlando la política - Ciudadanos y medios den las nuevas democracias latinoamericanas. Buenos Aires: Temas. 
DAGNINO, Evelina. 2002. "Sociedade Civil, Espaços Públicos e a Construção Democrática no Brasil: Limites e Possibilidades”. In:

Sociedade Civil e Espaços Públicos no Brasil. São Paulo: Paz e Terra. (coord). 1998-1999. "Os Movimentos sociais e a construção democrática”. Idéias, 5(2)/6(1), UNICAMP.

Dahl, Robert A. 1956. A preface to democratic theory. Chicago: University of Chicago Press.

1982. Dilemmas of pluralist democracy - Autonomy versus control. New Haven: Yale University Press.

DEBORD, Guy. 1998. A sociedade do espetáculo - Comentários críticos sobre a sociedade do espetáculo. Rio de Janeiro: Contraponto.

DERRIDA, Jacques. 1982; "Sending: On representation". Social Research n. ${ }^{\circ} 49$.

ELSTER, John (ed.) 1998. Deliberative democracy. Cambridge: Cambridge University Press.

FERNANDES, Rubem César. 2002. Privado, porém público - O terceiro setor na América Latina. Rio do Janeiro: Relume Dumará/Civicus.

FERRY, Jean-Marc. 1992. "Las transformaciones de la publicidad política". In: _ WOLTON, Dominique, et. alli. El nuevo espacio público. Barcelona: Gedisa.

, WOLTON, Dominique et. al. El nuevo espacio público. Barce-

lona: Gedisa92.

FIGUEIRED0, Rubens. 2000. "O marketing político: entre a ciência e a falta de ração". In: (org. ). Marketing político e persuasão eleitoral. Rio de Janeiro: Fundação Konrad Adenauer.

FRIEDMAN, Elisabeth Jay, HOCHSTETLER, Kathryn. 2002. “Assessing the Third Transition in Latin American Democratization. Representational Regimes and Civil Society Argentina and Brazil”. Comparative Politics, 35: 1, October.

FOX, Jonathan. 2006. "Sociedad civil y políticas de rendición de cuentas". Perfiles Latinoamrericanos, México, n. ${ }^{\circ}$ 27, janeiro-junho.

FUNG, Archon. 2004. Empowered Participation: Reinventing Urban Democracy. Princeton: Princeton University Press.

; WRIGHT, Eric Olin. 2003. "Thinking about Empowered Participatory Governance. "In: FUNG, Archon; WRIGHT, Eric Olin (Eds.), Deepening Democracy: Institutional Innovation in Empowered Participatory Governance. London: Verso.

GALVÃO, J. P. Sousa de. 1971. Da representação política. São Paulo: Saraiva. GAVENTA, John. 2004. "Representation, Community Leadership and Participation: Citizen Involvement in Neighbourhood Renewal and Local 
Governance". Paper prepared for the Neighbourhood renewal Unit Office of Deputy Prime minister, February 2004.

GINGRASS, Anne-Marie. 1998. "El impacto de las comunicaciones en las prácticas políticas”. In: GAUTHIER, Pilles, GOSSELIN, André e MOUCHON, Jean (eds. ). Comunicación y política. Barcelona: Gedisa.

GOMES DA SILVA, Tatiana de Amorim. 2003. "O enigma da esfinge. Indefinição entre o público e o privado: A relação dos conselheiros de direitos (2000-2002) com o fundo municipal dos direitos da criança e do adolescente de São Paulo”. Dissertação de Mestrado em Ciências Sociais, Pontifícia Universidade Católica de São Paulo.

GODDELIN, André, 1998. "La comunicación política - Cartografía de un campo de investigación y de actividades". In: GAUTHIER, Gilles; GOSSELIN, André; MOUCHON, Jean (compiladores). Comunicación y política. (1995) Barcelona: Gedisa.

GRINDLE, Merilee S. 1999. Audacious reforms - Institutional reform and democracy in Latin América. Baltimore: Johns Hopkins Universuty Press.

GURZA LAVALLE, Adrian. 1999. "Crítica ao modelo da nova sociedade civil”. Lua Nova, Cedec, n. ${ }^{\circ} 47$.

. 2003a. "Sem pena nem glória. O debate da sociedade civil nos anos 1990”. Novos Estudos, Cebrap, n. ${ }^{\circ} 66$.

Cedec, n. ${ }^{\circ} 59$. . 2003b. "Cidadania, igualdade e diferença". Lua Nova, ACHARYA, Arnab e HOUTZAGER, Peter. 2005. "Beyond Comparative Anecdotalism: Lesson on Civil Society and Participation from São Paulo, Brazil". World Development Special Edition, 'Exploring the Politics of Poverty Reduction: How are the poorest represented'.

, HOUTZAGER, Peter e CASTELLO, Graziela. 2006. "Representação Política e Organizações Civis - Novas Instâncias de Mediação e os Desafios da Legitimidade”. Revista Brasileira de Ciências Sociais, vol. 21, n. ${ }^{\circ}$ 60 (no prelo).

GUTMANN, Amy, e THOMPSON, Dennis. 2004. Why Deliberative Democracy? Princeton University Press.

HABERMAS, Jürgen. 1980. A crise de legitimação no capitalismo tardio. Rio de Janeiro, Tempo Brasileiro.

. 1987. The theory of communicative action II - Lifeworld and system: a critique os funcionalist reason. Boston, Bacon Press.

1993. "La soberanía popular como procedimiento - Un concepto normativo de lo público”. In: María Herrera (coord.). Jürgen Habermas - Moralidad, ética y política: propuestas y críticas. México, Alianza Editorial.

. "Três modelos normativos de democracia". Lua Nova, 
CEDEC, n. ${ }^{\circ} 36$.

1998. Facticidad y validez - Sobre el derecho y el Estado democrático de derecho en términos de teoría del discurso. Madri: Trotta.

HELLER, Patrick. 2001. "Moving the State: The Politics of Democratic Decentralization in Kerala, South Africa, and Porto Alegre". Politics E Society 29, n. ${ }^{\circ} 1$.

"Reinventing Public Power in the Age of Globalization: The Transformation of Movement Politics in Kerala”. In: RAY, R.; KATZENSTEIN, M. Fainsod (eds.). Social Movements and Poverty in India.

No prelo.

HOUTZAGER, Peter. "Introduction: From Polycentrism to the Polity. " In: e MOORE, Mick (eds.). 2003. Changing Paths: International Development and the New Politics of Inclusion. Ann Arbor: Michigan University Press. HARRIS, John, COLLIE, Ruth, GURZA LAVALLE, Adrián.

"Rights, representation and the poor: comparisons across Latin America and India”. LSE Working Paper Series $n .^{\circ} 2-3$, London School of Economics.

GURZA LAVALLE, Adrián e ACHARYA, Arnab. 2003. "Who Participates? Civil Society and the New Democratic Politics in São Paulo, Brazil”. IDS Working Paper n. ${ }^{\circ}$ 210, Institute of Development Studies/Univerity of Sussex. e 2004. "Atores da Sociedade Civil e Atores Políticos-Participação nas Novas Políticas Democráticas em São Paulo". In: AVRITZER, Leonardo (ed). Participação política em São Paulo. São Paulo: Unesp.

IMIG, Douglas. 1996. Poverty and power: the political representations of poor Americans. Lincoln: University of Nebraska Press.

ISAAC, T. M. Thomas and HELLER, Patrick. 2003. "Decentralisation, Democracy and Development: People's Campaign for Decentralised Planning in Kerela". In: FUNG, Archon and WRIGHT, Erik Olin, (eds.), Deepening Democracy: Instiutional Innovation in Empowered Participatory Governance. Londres: Verso.

KEANE, Jonh. 1988. Democracia y sociedad civil. México, Alianza Editorial. . 1992. La vida pública y el capitalismo tardío - Hacia una teoría socialista de la democracia. México: Alianza.

KLIKSBERG, Bernardo. 2000. "Seis tesis no convencionales sobre participación”. In: KLIKSBERG, Bernardo e TOMASSINI, Luciano. Capital social y cultural: claves estratégicas para el desarrollo. México: FCE/BID/Maryland U. KLINGEMANN, Hans-Dieter; HOFFERT, Richard \& BUDGE, Ian. 1994. Parties, Polices and democracy. Westview Press. 
LAISNER, Regina Cláudia. 2005. Poder local e experiências participativas: a implantação do orçamento participativo em São Paulo e Piracicaba (SP) numa perspectiva comparada. Tese de Doutorado em Ciência Política, USP-FFLCH.

LANDIM, Leilah. 1998. “'Experiência militante’: histórias das assim chamadas ONGs". In: (org. ). Ações em sociedade - Militâncias, caridade, assistência, etc. Rio do Janeirio: ISER/NAU.

LIPOVETKY, Pilles. 1986. La era del vacío. Ensayos sobre el individualismo contemporáneo. Barcelona: Ed. Anagrama.

MACPHERSON, C. B. 1978. A democracia liberal: origens e evolução. Rio de Janeiro: Zahar Editores.

MANIN, Bernard. 1995. "As metamorfoses do Governo Representativo". Revista Brasileira de Ciências Sociais, n. ${ }^{\circ}$ 29, ano 10, outubro.

University Press. 1997. The Principles of representative government. Cambridge: PRZEWORSKI, Adam e STOKES, Susan. "Eleições e Representação”. Neste volume, p. 49-104 1999. "Introduction".

In: STOKES, PRZEWORSKI e MANIN (eds.). Accountability, and representation. Cambridge: Cambridge University Press.

MIÈGE, Bernard. 1998. "El Espacio público: más allá de la esfera política". In: GAUTHIER, Gilles, GOSSELIN, André e MOUCHON, Jean. Comunicación y Política. Barcelona: Gedisa.

MIGUEL, Luis Felipe. 2003a. "Representação política em 3-D: elementos para uma teoria ampliada da representação política”. Revista Brasileira de Ciências Sociais, n. ${ }^{\circ}$ 51, ano 18, fevereiro.

. 2003b. "Impasses da accountability: dilemas e alternativas da representação política”. Paper apresentado no XXVII Congresso Anual da ANPOCS, Caxambu, outubro.

MOKRE, Monika. 2002. "Identities and representation - On the development of a European democracy". Österreich, IWE Working Paper Series n. ${ }^{\circ} 33$. NOVARO, Marcos. 2000. Representación y liderazgo en las democracias contemporáneas. Rosario: Homo Sapiens Ediciones.

O'DONNELL, Guillermo. 1998. "Accountability horizontal e novas poliarquías”. Lua Nova, CEDEC, n. ${ }^{\circ} 44$.

OLVERA, Alberto J. 2003. Sociedad civil, esfera pública y democratización en América Latina: México. México: Fondo de Cultura Económica: Universidad Veracruzana.

PATEMAN, Carol. 1970. Participation and Democratic Theory. London: Cambridge University Press.

PANFICHI, Aldo. 2003. Sociedad civil, esfera pública y democratización en Amé- 
rica Latina: Andes y Cono Sur. México: Fondo de Cultura Económica, Universidad Veracruzana.

PEREIRA, Luiz Carlos Bresser e NURIA, Cunill Grau. 1988. "Entre el Estado y el mercado: lo público no estatal”. In: e (eds). Lo público no estatal en la reforma del Estado. Argentina: CLAD/Paidós.

PERUZZOTTI, Enrique e SMULOVITZ, Catalina. 2002. "Accountability social: la otra cara del control". In: e . Controlando la política - Ciudadanos y medios den las nuevas democracias latinoamericanas. Buenos Aires: Temas.

PINT0, Céli Regina Jardim. 2004. "Espaços deliberativos e a questão da representação”. Revista Brasileira de Ciências Sociais, 19 (54), fev.

PITKIN, F. Hanna. 1967. The concept of representation. Berkeley: University of California Press. volume, p. 15-48.

"Representação - Palavras, instituições e idéias". Neste PRZEWORSKI, Adam. 2002. “Accountability social en América Latina y más allá”. In: PERUZZOTTI, Enrique e SMULOVITZ, Catalina. Controlando la política - Ciudadanos y medios den las nuevas democracias latinoamericanas. Buenos Aires: Temas.

. 1999. "Minimalist conception of democracy: A defense". In: SHAPIRO, Ian e HAKER-CORDON, Casiano. Cambridge: Cambridge University Press.

STOKES, Susan e MANIN, Bernard (eds.). 1999. Accountability, and representation. Cambridge: Cambridge University Press.

RAICHELIS, Raquel. 2000. Esfera pública e conselhos de assistência social: Caminhos da construção democrática. São Paulo: Cortez.

REHFELD, Andrew. 2000. "On Legitimacy and Political Representation”. Political Theory Workshop: University of Chicago.

ROBERTS, Kenneth M. 2002. "Party-society Linkages and Democratic representation in Latin America”. Canada, Canadian Journal of Latin American and Caribbean Studies, vol. 27, n. ${ }^{\circ} 53$.

, e WIBBELS, Erick. 1999. "Party systems and electoral volatility in Latin America: A test of economic, institutional, and structural explanations". American Political Science Review, vol. 93, n. ${ }^{\circ} 3$, September.

ROSANVALLON, Pierre. 1992. La consagración del ciudadano - Historia del sufragio efectivo en Francia. México: Instituto Mora.

ROUSSEAU, Jean-Jacques. 1982. El contrato social o principios de derecho político. (1762). México: Editorial Porrua.

SADER, Eder. 1988. Quando Novos Personagens entram em cena. São Paulo, Paz e Terra. 
SANTOS, Boaventura de Sousa. 1998. "Participatory Budgeting in Porto Alegre: Toward a Redistributive Democracy”. Politics E $\mathcal{F}^{\text {Society } 26, \text { n. }}{ }^{\circ} 4$. 2002a. "Para Ampliar O Cânone Democrático. " In: Santos, Boaventura de Sousa (ed.), Democratizar a Democracia: Os Caminhos da Democracia Participativa. Rio de Janeiro: Civilização Brasileira. . 2002b. Democracia e Participação: O Caso do Orçamento Participativo de Porto Alegre. Porto: Edições Afrontamento.

SANTOS, Wanderley Guilherme dos. 1994. As razões da desordem. Rio de Janeiro: Rocco.

SARTORI, Giovanni. 1962. "A teoria da representação no Estado Representativo moderno”. In: Revista Brasileira de Estudos Políticos. Minas Gerais. cas. São Paulo: Ática. 1994. A teoria da democracia revisitada - 2. As questões teóri1997. Homo videns: televisão e pós-pensamento. São Paulo:

Edusc.

SCHMITTER. 1992. "The Consolidation of Democracy and Representation of Social Groups”. American Behavioral Scientist, n. ${ }^{\circ}$ 35, March-June.

SCHUMPETER, Joseph. Capitalismo, socialismo e democracia. 1942. Rio de Janeiro: Zahar.

102 SEIDLE, Leslie F. 1993. Equity and community: The Charter, interest ad
and representation. Montreal: Institute for research in Public Policy.

SORJ, Bernardo. 2005. "Civil Societies North-South Relations: NGOs and Dependency”. Working Paper $n .^{\circ} 1$, Rio de Janeiro: Edelstein Center for Social Research.

TATAGIBA, Luciana. 2002. "Os Conselhos Gestores e a Democratização das Políticas Públicas no Brasil”. In: DAGNINO, Evelina. Sociedade Civil e Espaços Públicos no Brasil. São Paulo: Paz e Terra.

TENZER, Nicolas. 1992. La Sociedad Despolitizada. Ensayo sobre los fundamentos de la política. Barcelona: Ediciones Paidós.

THOMPSON, John B. 1998. A mídia e a modernidade — Uma teoria social da mídia. Petrópolis: Vozes.

. 2002. "El papel del escándalo en la política". In: PERUZ-

ZOTTI, Enrique e SMULOVITZ, Catalina. Controlando la política-Ciudadanos y medios den las nuevas democracias latinoamericanas. Buenos Aires: Temas.

TOURAINE, Alain. 1992. "Comunicación política y crisis de la representatividad". In: FERRY, Jean-Marc, WOLTON, Dominique et al. El nuevo espacio público. Barcelona: Gedisa.

URBINATI, Nadia. 1999. "Rhetoric and Representation: The politics of advocacy”. Political Theory Workshop: University of Chicago. . "O que torna a representação democrática”. Neste volu- 
me, p.191-228.

WARREN, Mark E. 2005. "Citizen Representatives". Comments for the Roundtable: Mobilizing Representation Forty Years After Pitkin, APSA.

WOLTON, Dominique. 1992. "La comunicación política: construcción de un modelo". In: FERRY, Jean-Marc, et. alii. El nuevo espacio público. Barcelona: Gedisa.

1998. "Las contradicciones de la comunicación política". In: GAUTHIER, Gilles, GROSSELIN, André e MOUCHON, Jean (compiladores). Comunicación y política. Barcelona: Gedisa.

YOUNG, Iris Marion. 2002. Inclusion and democracy. Oxford: Oxford University Press.

volume, p.139-190.

"Representação política, identidade e minorias". Neste

ZERMEÑO, Sergio. 1990. "El regreso del líder". Revista del CLACSO, n. ${ }^{\circ} 56$, Buenos Aires, abril. 


\section{( )}

\section{DEMOCRACIA, PLURALIZAÇÃO DA REPRESENTAÇÃO E} SOCIEDADE CIVIL

ADRIÁN G. LAVALLE, PETER P. HOUTZAGER E GRAZIELA CASTELLO

$\mathrm{O}$ artigo problematiza a relação entre representação política e reforma da democracia, mostrando tanto os deslocamentos analíticos das abordagens centradas no sistema político e na reconfiguração da representação quanto as omissões das literaturas preocupadas com a reforma ou o aprofundamento da democracia. Inovações teóricas e práti- 
cas para se pensar no futuro da representação parecem reunir elementos que traspassam as fronteiras da compreensão e da prática liberais da representação política. A partir do resgate crítico da idéia de "representação virtual", os autores sugerem, então, uma agenda de reforma da democracia capaz de incorporar essas inovações.

Palavras-chave: Representação política; Reforma da democracia; Aprofundamento da democracia; Sociedade civil.

\section{DEMOCRACY, PLURALIZATION OF REPRESENTATION AND CIVIL SOCIETY}

The article issues on the relationship between political representation and democratic reform, presenting both analytic displacements from the approaches focused on the political system and the reshuffling of representation, and the omissions of the literature concerned on deepening democracy. Recent theoretical and practical innovations, which bring about much thinking on the future of representation, 266 seem to assemble elements that supersede the limits of the liberal understanding and practice of political representation. Out of the critical rescue of the idea of "virtual representation", the authors suggest an agenda of democratic reform that could be able to account for those innovations.

Keywords: Political representation; Democratic reform; Deepening democracy; Civil society. 